\title{
The relationships of the leadership styles of superintendents and fiscal conditions with district student performance across Ohio
}

Daniel T. Doyle

West Virginia University

Follow this and additional works at: https://researchrepository.wvu.edu/etd

\section{Recommended Citation}

Doyle, Daniel T., "The relationships of the leadership styles of superintendents and fiscal conditions with district student performance across Ohio" (2010). Graduate Theses, Dissertations, and Problem Reports. 4582.

https://researchrepository.wvu.edu/etd/4582

This Dissertation is protected by copyright and/or related rights. It has been brought to you by the The Research Repository @ WVU with permission from the rights-holder(s). You are free to use this Dissertation in any way that is permitted by the copyright and related rights legislation that applies to your use. For other uses you must obtain permission from the rights-holder(s) directly, unless additional rights are indicated by a Creative Commons license in the record and/ or on the work itself. This Dissertation has been accepted for inclusion in WVU Graduate Theses, Dissertations, and Problem Reports collection by an authorized administrator of The Research Repository @ WVU.

For more information, please contact researchrepository@mail.wvu.edu. 
The Relationships of the Leadership Styles of Superintendents and Fiscal Conditions with District Student Performance across Ohio

\author{
Daniel T. Doyle
}

Dissertation submitted to the College of Human Resources and Education

at West Virginia University in partial fulfillment of requirements

for the degree of

Doctor of Education

In

Educational Leadership Studies

\author{
Paul Chapman, Ph.D. Chair \\ Ernest Goeres, Ph.D. \\ Jerry Klenke, Ph.D. \\ Neal Shambaugh, Ph.D. \\ Ted Price, Ph. D. \\ Department of Advanced Educational Studies \\ Morgantown, West Virginia \\ 2010
}

Keywords: Superintendent Leadership Styles, Public School Funding Conditions (Predictability - Sustainability), District Student Performance.

Copyright 2010, Daniel T. Doyle 


\begin{abstract}
The Relationships of the Leadership Styles of Superintendents and Fiscal Conditions with District Student Performance across Ohio
\end{abstract}

\title{
Daniel T. Doyle
}

This study investigated the relationships of the leadership styles of superintendents and the fiscal conditions of local school districts with student performance across Ohio. To examine these relationships the Bolman and Deal survey instrument, "Leadership Behavior Description Questionnaire-Self," was utilized to collect data from superintendents to assess their perception of their leadership style. The fiscal conditions of the school districts were placed on predictability and sustainability continuums based upon state percentage basic aid and annual percentage change in per pupil expenditure over five Ohio state biennial funding cycles (1997-2007). Control variables for the study include district size, socio-economic status, locale and per pupil expenditure. Surveys were sent to superintendents serving the 614 public school districts across Ohio. Responses were received from 241 superintendents. 174 surveys were utilized for an inclusive analysis and 83 qualified for the primary study. An ancillary analysis was completed to investigate more deeply the relationships between district fiscal conditionpredictability and district student performance with the study variables. Descriptive statistics were utilized as were linear multiple regression models to provide the statistical analysis.

Major research findings indicate: (1) Superintendents across Ohio champion the multiframed leadership style (35\%) followed by the single frame $(27 \%)$ and the paired and the no-frame style (19\%) equally; (2) Within these styles the structural frame (30.2\%) was utilized the most, followed by the human-resource (26.3\%), the symbolic and political (17.1\%) equally and the no-frame $(9.3 \%)$; (3) None of the study variables were found to be significant with leadership styles; (4) As a school district's fiscal conditionsustainability increases, so does the district expenditure per pupil and the district fiscal condition-predictability; (5) As a school district's fiscal condition-predictability increases, so does the number of students qualifying for the free/reduced lunch program and the district fiscal condition-sustainability. However, as the school district also becomes smaller, the district expenditure per pupil becomes less and the district is more likely to be urban than suburban; and (6) As a school district's student performance increases its fiscal condition-predictability and fiscal condition-sustainability becomes lower.

Recommendations from this study include: (1) Implementation of professional development activities for superintendents that includes an understanding in leadership styles along with an increased awareness of their personal leadership style; and (2) opportunities provided for federal, state and local funding policy makers to gain an awareness of the relationships between a school district's dependency on state basic aid and the district student performance. 


\section{Acknowledgements}

Completion of this doctoral program would not have been possible without the support, understanding and encouragement of many people. I would first like to thank my Committee Chair, Dr. Paul Chapman for adopting me on a short notice and leading me to completion; second to Dr. Richard Hartnett whom without his patience, guidance and continued counsel I would not have been successful at completing this most challenging task; and, third to Dr. Ted Price for willingly agreeing to join my committee at the $24^{\text {th }}$ hour. My sincerest appreciation is extended to the doctoral committee members Dr. Paul Chapman, Dr. Ernest Goeres, Dr. Neal Shambaugh, Dr. Ted Price and Dr. Jerry Klenke, who have all provided thoughtful and constructive feedback while providing guidance and support that I needed. I now have a great appreciation when I call you "Doctor".

Many people have made this possible, to my colleague, Dr. Dianna Vargo for cheering and supporting me; to my administrative assistant, Linda Winegardner for her editing and typing skills and for her patience with me throughout this process; and to Dr. Bill Welker and Mrs. Beth Wesson for proofreading my document, thank you. I extend my utmost gratitude to Dr. Aimee Howley at Ohio University, who without her statistical wisdom, research methodology and knowledge of Ohio Public Schools this would never have been possible. I thank you for your patience and persistence. Only God could have sent you my way.

Finally I would like to thank my family, especially my wife Cindy, who has been there by my side throughout this long journey and has never complained about the long hours of study and waiting. To my father, whom I miss dearly, that motivated me to seek this 
degree. I remember him telling me and my siblings, "They can take everything away from you in this world except your education," thanks dad! 
Table of Contents

Abstract

ii

Acknowledgements

iii

$\underline{\text { Table of Contents }}$ V

Appendix viii

$\underline{\text { Table's }}$ ix

Chapter 1 - Introduction to the Study 1

$\underline{\text { Introduction }}$ 1

Statement of the Problem 5

$\underline{\text { Research Questions }}$ 5

Definition of Terms 6

Significance of the Study 11

Limitations of the Study 13

Summary of the Chapter 14

Chapter 2 - Literature Review 16

Leadership Styles 16

Superintendents Leadership 24

$\underline{\text { School Funding }}$ 28

$\underline{\text { School Size }}$ 32

$\underline{\text { Socio-economic Conditions }}$ 35

$\underline{\text { Locale }}$ 39

Per pupil expenditure 40 
Research Design $\quad 43$

\begin{tabular}{lr} 
Population/Participants & 44 \\
\hline
\end{tabular}

Instrumentation $\quad 45$

\begin{tabular}{lr} 
Procedure & 47 \\
\hline
\end{tabular}

Data Analysis $\quad 47$

Confidentiality and Anonymity $\quad 52$

\begin{tabular}{lr} 
Summary & 52 \\
\hline
\end{tabular}

Chapter 4-Results $\quad 54$

Survey Respondents $\quad 54$

Variable Descriptive Statistics... $\quad 56$

\begin{tabular}{lr} 
Correlation Matrices & 58 \\
\hline
\end{tabular}

\begin{tabular}{lr} 
Regression Model & 61 \\
\hline
\end{tabular}

\begin{tabular}{lr} 
Research Questions & 62 \\
\hline
\end{tabular}

\begin{tabular}{lr} 
Ancillary Analysis & 78 \\
\hline
\end{tabular}

\begin{tabular}{lr} 
Summary & 81 \\
\hline
\end{tabular}

Chapter 5-Conclusion and Recommendations $\quad 84$

Summary of Study $\quad 84$

\begin{tabular}{lr} 
Conclusions & 85 \\
\hline
\end{tabular}

Patterns of Superintendent Leadership Styles $\quad 85$

Relationships with Leadership Styles $\quad 88$

Relationships with District Fiscal Condition-Sustainability $\quad 88$

Relationships with District Fiscal Condition-Predictability $\quad 89$

Relationships with District Student Performance $\quad 91$ 
$\underline{\text { Relationships with District Fiscal Condition-Predictability } 93}$ 


\section{Appendix}

A. Calculating the Performance Index 108

B. Survey Instrument "Leadership Orientations (Self)" 118

C. Letter for Permission to use "Leadership Orientations (Self)" Instrument

D. Initial Introduction Letter to Superintendents 123

E. Follow-up Letter to Superintendents 124

F. Approval for Expedited - IRB Protocol Exemption. 125

G. Certification of Human Participant Protection Training 126 
Tables

Table 1 Overview of the Bolman \& Deal Four Frame Model 16

Table 2 Treatment Differentials among Groups and Curricular Tracks: Patterns of Discrimination in Lower Ability Groups 36

Table 3 The Structure of the Bolman \& Deal Leadership Orientation (SELF) Survey 46

Table 4 Study Variable Abbreviations and Type 51

Table 5 Data Table Example 51

Table 6 Frequency Distribution of Participants by Gender 55

Table 7 Frequency Distribution of Participants by District Locale 55

Table $8 \quad$ Means and Standard Deviations of Study Variable - Inclusive. $\quad 56$

Table $9 \quad$ Mean and Standard Deviations of Study Variable - Qualifying $\quad 57$

Table $10 \quad$ Means and Standard Deviations of Study Variable - Statewide. $\quad 57$

Table $11 \quad$ Pearson Correlations for Study Variables - Inclusive $\quad 58$

Table 12 Pearson Correlations for Study Variables - Qualifying $\quad 59$

Table $13 \quad$ Pearson Correlations for Study Variables - Statewide $\quad 60$

Table $14 \quad$ Frequency Distribution of Participants by Frame Pattern $\quad 63$

Table $15 \quad$ Utilization of Frame through

Reported Frequency Pattern - Inclusive 65

Table $16 \quad$ Utilization of Frame through Reported Frequency Pattern - Qualifying 65

Table $17 \quad$ Frequency Distribution of Leadership Style by Gender $\quad 66$

Table 18 Summary of Regression Analysis for Variables Influencing Superintendent Leadership Style - Inclusive 66

Table 19 Summary of Regression Analysis for Variables Influencing Superintendent Leadership Style - Qualifying 67 
Table 20 Summary of Regression Analysis for Variables Influencing Fiscal Condition-Sustainability - Inclusive 68

Table 20.1 Summary of $R^{2}$ Values for Regression Models through Block Method - Inclusive

Table $21 \quad$ Summary of Regression Analysis for Variable Influencing Fiscal Condition-Sustainability - Qualifying 70

Table 21.1 Summary of $R^{2}$ Values for Regression Models through Block Method - Qualifying 71

Table 22 Summary of Regression Analysis for Variables Influencing Fiscal Condition-Predictability - Inclusive 72

Table 22.1 Summary of $R^{2}$ Values for Regression Models through Block Method - Inclusive 72

Table 23 Summary of Regression Analysis for Variables Influencing Fiscal Condition-Predictability - Qualifying 73

Table 23.1 Summary of $R^{2}$ Values for Regression Models through Block Method - Qualifying 74

Table 24 Summary of Regression Analysis for Variables Influencing District Student Performance - Inclusive 75

Table 24.1 Summary of $R^{2}$ Values for Regression Models through Block Method - Inclusive 76

Table 25 Summary of Regression Analysis for Variables influencing District Student Performance - Qualifying 76

Table 25.1 Summary of $R^{2}$ Values for Regression Models through Block Method - Qualifying 77

Table 26 Summary of Regression Analysis for Variables Influencing Fiscal Condition-Predictability - Statewide 78

Table 26.1 Summary of $R^{2}$ Values for Regression Models through Block Method - Statewide 79

Table 27 Summary of Regression Analysis for Variables Influencing District Student Performance - Statewide 80

Table 27.1 Summary of $R^{2}$ Values for Regression Models through Block Method - Statewide 


\section{CHAPTER 1}

\section{Introduction}

The economic challenges facing American schools are unprecedented. These anxieties, coupled with student performance as cross national comparisons reveal deficiencies in our system; the need for imaginative and courageous leadership at all levels is critical. Studies investigating the relationships of school district fiscal conditions and the leadership styles of school leaders with student performance could not be more timely than today.

The purpose of this study was to investigate the relationship of leadership styles and fiscal conditions, namely predictability and stability, with district level student performance in Ohio. Since other conditions are likely to influence district performance, the model utilized in this study includes additional independent variables as controls, namely: district size, socio-economic status, locale, and per pupil expenditure.

The 2007 American Association of School Administrators (AASA) publication, The State of the American School Superintendency: Mid-Decade Study, stated "Good leadership ability is the reason given by nearly half (49.2\%) of superintendents as the most important reason their boards hire them" (p 68). Considerable research has been completed investigating the significance of building level leadership, specifically by the principal. However, until recently little research has been completed investigating the significance or the relationships of the leadership at the central office and more specifically that of the superintendent. Waters and Marzano (2006) found that superintendents' leadership has a positive effect on district student achievement. The lack of research on the influence of the leadership of the superintendent and recent 
findings such as those of Waters and Marzano make it apparent that research investigating the relationships of the superintendents' leadership is necessary.

According to theory, a leader who is able to utilize a greater number of perspectives or frames is better able to gather complete information to assess situations and organizations, make clear judgments and take effective actions (Turley, 2002). A leader's ability to utilize these perspectives or frames is considered their leadership style. This study also investigated the relationships of the leadership styles of superintendents with the performance of the students within their district.

The American Association of School Administrators (AASA) "State of the American School Superintendency" (2007) publication states, "that the participants in all five AASA studies dating back to 1960 , listed inadequate funding as being the number one factor inhibiting their ability to be effective" (p 55). Present research has also found that the wealth of a district positively influences student achievement. With the enactment of "The No Child Left Behind Act" and the newly created environment of increasing accountability, research on the relationships of the fiscal conditions of school districts with student performance is needed.

On four occasions since 1997 the school funding system utilized to fund public education in Ohio has been ruled unconstitutional by the State Supreme Court in DeRolph v. State (1997), 78 Ohio St.3d 193, 677 N.E.2d 733, (“DeRolph I”); DeRolph v. State (2000), 89 Ohio St.3d 1,728 N.E.2d 993 (“DeRolph II”); DeRolph v. State (2001), 93 Ohio St.3d 309, 310, 754 N.E.2d 1184 (“DeRolph III”); and DeRolph v. State, 97 Ohio St.3d 434, 2002-Ohio-6750(“DeRolph IV”). Some of the issues addressed in these DeRolph cases add to the necessity of this study. For example does the system utilized to 
fund public education: (1) provide an adequate amount of resources to educate a child, (2) provide the resources in an equitable manner statewide and (3) does this adequate and equitable system provide a thorough and efficient education? Lawsuits questioning state systems of funding public education are not unique to Ohio for to date no fewer than 45 states have encountered lawsuits challenging their systems of funding public education (Hirth \& Eiler, 2005). Without a predictable and sustainable system of school funding these issues common to these challenges cannot be resolved.

The importance of fiscal predictability and stability for public school districts is evident in the research of Ammar, Duncombe, Jump, and Wright (2005). They define the fiscal condition of a school district as the ability to finance educational services to assure adequate resources for student performance over the long run without temporary disruption of services. Fiscal predictability and stability are necessary as organizations make daily decisions and plan for the future. There exists much research on the influence of fiscal predictability and stability on private and public organizations; however, research on the relationships of fiscal predictability and stability with student performance as done in this study is limited.

The unconstitutional system of school funding in Ohio has resulted in school districts experiencing unpredictable state support for public K-12 education. The resulting irregular funding creates boom and bust cycles for school districts, especially those that depend heavily upon state aid. Ohio schools during the ten year period of this study were funded through a foundation program. A minimum foundation (per pupil) amount was established three different ways over the time period of this study. From 1997 until 2002 this amount was determined through residual budgeting by the Ohio 
General Assembly. From 2002 until 2006 the Ohio General Assembly determined this amount through an inferential method determined by Dr. John Augenblick. From 2005 through the 2007 a building block method was utilized. The building block method represented a dollar amount for teaching personnel, non-teaching personnel and nonpersonnel costs. The local share of this foundation amount is determined based upon the property valuation of the local district. Every district being charged off the local share of the state formula at 23 mills multiplied by the property value

Salmon \& Alexander (1976) describes the ability of school district to generate dollars through it property valuation as "fiscal capacity." As such, school districts with high property valuation (high wealth) have great fiscal capacity and those with small property valuation (low wealth) have low fiscal capacity. Today's economic conditions have resulted in moderate, if any increase in state aid to school districts across Ohio. Sack (2004) discovered, "The gap in school funding between wealthy and poor districts is growing in most states, a striking reversal of progress made during better economic times" (p 1). Without fiscal predictability and sustainability, resources for maintaining and improving student performance will become scarce, especially in poorer school districts.

In conclusion, considerable research has been completed on the influence of district size, district socio-economic status, district locale and district per pupil expenditure on student performance; however, limited research can be found on the relationships of leadership styles of superintendents and district fiscal conditions (predictability and sustainability) with student performance. 


\section{Statement of the Problem}

This study examined the relationships that leadership styles of superintendents and the fiscal conditions within school districts across Ohio have with district student performance. Relationships examined are: (1) The relationships of the leadership styles of superintendents with district student performance; (2) The relationships of the fiscal conditions (predictability and sustainability) of the school district with district student performance; and (3) If found to exist, the combined relationships of the leadership styles of superintendents and the fiscal conditions (predictability and sustainability) of school districts with district student performance.

The leadership styles utilized within this study are based upon the foundation of Bolman and Deal's (2003) cognitive frames (structural, human resource, political, and symbolic) to understand organizational behaviors and governance patterns.

\section{Research Questions}

This research investigated the relationships of leadership styles, district fiscal condition, superintendents' gender, district size (ADM), district socio-economic status, district locale and district per pupil expenditure with district student performance.

The study invited qualifying superintendents from the 614 public school districts across Ohio to participate.

The study sought to answer the following five research questions:

Question 1: What are the leadership styles (as measured by the four frames) of the superintendents across Ohio?

Question 2: In consideration of appropriate control variables, what are the individual and combined relationships of superintendents' gender, district size, district socio-economic 
status, locale, per pupil expenditures, district fiscal condition - sustainability and district fiscal condition - predictability with superintendents' leadership styles?

Question 3: In consideration of appropriate control variables, what are the individual and combined relationships of superintendents' gender, district size, district socio-economic status, locale, per pupil expenditures, leadership style and district fiscal condition predictability with the district fiscal condition - sustainability?

Question 4: In consideration of appropriate control variables, what are the individual and combined relationships of superintendents' gender, district size, district socio-economic status, locale, per pupil expenditures and district fiscal condition - sustainability with the district fiscal condition - predictability?

Question 5: In consideration of appropriate control variables, what are the individual and combined relationships of superintendents' gender, district-level fiscal condition sustainability, district-level fiscal condition - predictability, and superintendents' leadership style with district student performance?

\section{Definition of Terms}

The terms mentioned here in brief will be discussed in greater detail in Chapter 2.

\section{District Student Performance}

Information from the Ohio Department of Education (ODE) will provide the necessary data for the dependent variable district student performance. Every school district across Ohio receives a Performance Index (PI). This value is an indicator of the performance of students from a district compared to districts statewide.

The Performance Index (PI) is a calculation that measures Ohio Achievement Tests

(OAT)/Ohio Graduation Test (OGT) performance at the $3^{\text {rd }}, 4^{\text {th }}, 5^{\text {th }}, 6^{\text {th }}, 7^{\text {th }}, 8^{\text {th }}$, and $10^{\text {th }}$ 
(OGT) grade levels based upon the number of students at each performance level. The PI is calculated by assigning a weighted score to each performance level using the Performance Index Calculation detailed in Appendix A.

For analysis purposes, the Performance Index school districts receive will be placed on a continuum from the lowest to highest.

\section{The Four Leadership Frames}

According to Bolman and Deal (2003), organizations function from the four perspectives or four frames: the structural, the human resource, the political, and the symbolic. Accordingly, leadership styles reflect these frames. Successful leaders must be able to reframe their leadership styles to be successful. Leadership styles are based upon the core beliefs of these frames.

The structural frame. Leaders who follow the structural frame have a belief in rationality and a faith that the right formal arrangements minimize problems and maximize performance. The structural leader champions a pattern of (well-thought-out) roles and relationships (Bolman \& Deal, 2003).

The human resource frame. Leaders using this frame believe organizations exist to serve human needs rather than the reverse. People and organizations need each other and a good fit benefits both. Organizations operating from the human resource frame promote openness, participation, empowerment, and view members as the primary resource (Bolman \& Deal, 2003).

The political frame. Leaders within organizations that operate from the political frame view the organization as living, screaming political arenas that host a complex web of individuals and group interests. There exist enduring differences among members in 
values, beliefs, information, interests, perceptions of reality, arenas of conflict and acknowledgement of competition for scarce resources. Leaders operating within this frame would spend much of their time networking, creating coalitions, building a power base, and negotiating compromises (Bolman \& Deal, 2003).

The symbolic frame. Leaders operating from this frame understand life within the organization is viewed as more serendipitous than linear, "Culture is the glue that holds an organization together and unites people around shared values and beliefs" (Bolman \& Deal, 2003, p 243). The leader operating with this frame understands the importance of myth, rituals, ceremonies, stories, and other symbolic activities.

\section{Leadership Orientation Styles}

The no-frame orientation leadership style. The superintendent who does not implement any of the frame orientations is assumed to demonstrate a leadership style with none of the four frames discussed above (Bolman \& Deal, 1992, 2003).

The single-frame orientation leadership style. The superintendent who utilizes one of the frames discussed is said to operate from a single-frame style (Bolman \& Deal, 1992, 2003).

The paired-frame orientation leadership style. The superintendent who operates from within two of the frames discussed champions a paired-framed style (Bolman \& Deal, 1992, 2003).

The multiple-frame orientation leadership style. The multiple-frame orientation leadership style would indicate the superintendent is utilizing three or more of the frames discussed (Bolman \& Deal, 1992, 2003) 
For analysis purposes the leadership styles of the superintendents are placed on the following scale: 0 representing the no leadership frame orientation leadership style; 1 representing the single-frame orientation leadership style; 2 representing the paired-frame orientation leadership style; and 3 representing the multiple-frame orientation leadership style.

\section{School District Fiscal Conditions}

Sustainability. The sustainability variable of the school district fiscal conditions is determined through information of the school district's average per pupil expenditure provided by ODE. The annual average per pupil expenditure, $(\%)$ increase/decrease, is calculated for the school districts in Ohio over the past five biennium funding cycles (1997-2007).

This data can be found placed on a continuum from lowest to highest for analysis purposes.

Predictability. The predictability variable of the school district fiscal conditions will be determined through information about the state share of funding to school districts provided by ODE. The annual average in state share of funding for school districts will be calculated over the same time period $(1997-2007)$ as the predictability variable.

For analysis, this annual average in state share of funding will be placed on a continuum from lowest to highest.

\section{Control Variables}

School size. The school size variable will be determined through the school district's Average Daily Membership (ADM) information received from ODE that the state uses to calculate district student enrollment. 
For analysis, district's Average Daily Membership (ADM) will be placed on a continuum from lowest to highest.

Socio-economic status. Socio-economic status data will be measured by information received from ODE data reflecting the district percentage of students receiving federally subsidized free or reduced lunch.

These actual percentages will placed on a continuum for analysis purpose from the lowest percentage of students qualifying to the highest.

Locale. Information from the National Center for Educational Statistics (NCES) will provide the necessary data for the locale. The 614 school districts across Ohio are classified as: city large, city mid-sized, city small, suburb large, suburb mid-size, suburb small, town fringe, town distant, town remote, rural fringe, rural distant, and rural remote as classified by the most recent NCES locale codes.

For analysis purposes, districts classified by NCES as city large, city mid-sized, and city small will be given a value of 1 and classified as urban. Districts classified as suburb large, suburb mid-size, suburb small by NCES will be classified as suburban given a value of 2. Districts classified as town fringe, town distant, town remote, rural fringe, rural distant and rural remote by NCES will be classified as rural and receive a value of 3 .

Per pupil expenditure. Per pupil expenditure, FY 2007 (actual dollars spent) for each of the 614 public school districts will be provided through information from ODE.

For analysis purposes these values will be placed on a continuum from lowest to highest. 


\section{Significance of Study}

This completed study investigated the relationships of leadership styles of superintendents, superintendents' gender, the fiscal conditions and other selected control variables in school districts across Ohio with district student performance. This study replicated other studies that have investigated the relationships of superintendents' gender, district size, socio-economic status, locale and per pupil expenditure with student district performance while focusing on the relationships of the leadership styles of the superintendent and the fiscal conditions (sustainability and predictability) of the school district.

If not the first, this investigation should prove to be one of very few studies that measure the relationships of leadership styles of superintendents and fiscal conditions (predictability and stability) with students' performance. If the fiscal conditions have a strong relationship with student performance, the relationships of leadership style becomes of greater importance to researchers, practitioners, policymakers and administrator training programs.

There has been a significant amount of research on the relationships of principals' leadership and the actions of the superintendent with district student performance. Few if any studies have been completed investigating the relationships of the leadership styles of superintendents with district student performance.

This study may provide information that erodes the notion of the lack of linkage between the leadership of the superintendent and student performance. This study may well lead us to identify what it is that the superintendent is actually doing that affects their students' performance. 
There has been a significant amount of research on the relationships of various fiscal conditions on district students' performance and on the importance of predictable and sustainable fiscal conditions within private organizations, but little or no research has been completed investigating the relationships of predictability and sustainability of school district fiscal conditions with district student performance.

The results of this study will provide practicing administrators (superintendents) a better understanding of the relationships between leadership styles and fiscal conditions with student performance. The findings of this study will provide administrators (superintendents) with information to examine their own personal leadership style and the fiscal conditions within their school districts, enabling them to achieve maximum district student performance.

The findings within this study will provide necessary information to the administrator training programs, providing insight into the affects of leadership styles and fiscal conditions on student performance that is rarely if at all mentioned in these programs. Today's state and federal accountability systems require schools to maximize their students' performance; this study will provide another lens to be used to investigate how best to maximize student performance.

Policymakers will be able to use information gathered in this study in several ways. Individuals who are responsible for writing policy to maximize student performance will find the information gained valuable in guiding them in their discussions of the resources necessary to maximize student performance. Individuals writing policy on school funding would find the information on the relationships of the predictability and sustainability of school funding with student performance invaluable. 
Information gained from this study would be beneficial to these individuals as they create policy addressing the issues common to lawsuits nationwide challenging the states' systems of school funding. The private and public organizations that provide superintendent search services nationally and locally could use the findings within this study to better match a candidate's leadership style with the fiscal conditions of the district to maximize district student performance. There are several reasons to employ a superintendent and the findings of this study provide another lens to be utilized by school boards of education in selecting the best candidate for their school system.

Results of prior studies reporting on the relationships of the control variables utilized in this study: district size, socio-economic status, locale and per pupil expenditure on district student performance vary considerably. Studies such as this one are necessary to reinforce and give validity to those studies yielding similar results.

This study will provide information for professional practitioners whose actions are driven by the latest research and the knowledge of best practices that strengthen the links between research, policy, and practice. Today's state and federal accountability requires practitioners to be aware of the findings of this study and similar projects.

\section{Limitations of the Study}

Limitations of this study are the result of the individuals who participate in the study, those individuals who translated the results, and those who are inherent to research of this type.

How participating superintendents view themselves may construe their leadership styles limiting the accuracy of the research. That is, their different experiences, academic specializations, and personalities may influence each superintendent's perceptions of the 
surveys they complete. Hopefully, the superintendents of Ohio will see value to this study and took the time to complete the survey properly and in a timely fashion.

Research of this type may have findings that are not addressed as the result of the researcher's background and experiences.

Limitations inherent to research of this type can occur as the result of the construction of the variables that represent data over a short period of time. A sudden increase or decrease in variables constructed over a short period of time may result in the construing of the data. Variables in this research that reflect data over a short period of time (one year) include: a) Performance Index (PI), b) district size (ADM), c) locale and d) socio-economic status. The variable fiscal conditions (predictability and stability) were constructed from a ten year average and this data would be less likely to construe the results.

Lastly, this study is limited to quantitative data, and while the results presented will be an interpretation of this data, qualitative research studies often result in a deeper understanding of why these results occurred.

\section{Summary}

Effective school districts have effective leadership! Effective leaders are able to navigate the fiscal conditions of their district. Theory indicates that leaders who are able to utilize a greater number of perspectives or frames are better able to gather complete information to assess situations and organizations to make clear judgments and take effective actions. This study examined the relationships of the leadership style of the superintendent and the fiscal funding conditions of school districts across Ohio with district student performance. Through an analysis of data provided by the Ohio 
Department of Education and the use of Bolman and Deal's (2003) four-frame leadership model and leadership styles, this study explored the relationships between these variables.

This chapter briefly introduced the plan to study the relationships of the leadership styles of superintendents and fiscal conditions with district student performance across Ohio. Chapter 1 has outlined and developed the statement of the problem, presented the research questions to be answered, described the significance and limitations of the study, and provided a summary.

In the remaining paper: Chapter 2 will provide a detailed literature review related to the study variables: leadership frames and styles, superintendent leadership, school funding (fiscal conditions), district size, district socio-economic status, district locale and district per pupil expenditure. Chapter 3 will describe the methodology utilized in this study and contains six sections: the research design, the population/participants, instrumentations, the procedure, the data analysis, confidentiality and anonymity along with a brief summary. Chapter 4 will present the results of the study and Chapter 5 will discuss the research findings and present conclusions and suggestions for further research. 


\section{CHAPTER 2}

\section{Literature Review}

This chapter reviews major literature related to leadership styles, superintendent leadership, fiscal conditions of school districts and their relationships with district student performance. The review will also include literature describing the relationships of the control variables: school size, socio-economic status, locale, and per pupil expenditure with student performance, but not to the extent of the others.

\section{Leadership Styles}

Organizations are very complex and cannot be viewed through a single frame or perspective by leadership. Research indicates that the leader who is able to operate from the greatest number of perspectives or frames is found to be most effective (Turley, 2002). Effective leaders in complex organizations must understand their strengths and work to expand them, for without this vision error and self-isolation may occur. In summary, each frame is unique and is characterized by different beliefs and assumptions that are helpful in different circumstances for the effective leader. Table 1 illustrates an overview of the Bolman and Deal's four-framed model theory that will be utilized in this study to determine the leadership style of the participants (see Table 1).

\section{Table 1}

Overview of the Four Frame Model.

\begin{tabular}{lllll}
\hline Frame & Structural & Human Resource & Political & Symbolic \\
\hline $\begin{array}{l}\text { Metaphor } \\
\text { for Organization }\end{array}$ & $\begin{array}{l}\text { Factory or } \\
\text { machine }\end{array}$ & Family & Jungle & $\begin{array}{l}\text { Carnival } \\
\text { temple, theater }\end{array}$ \\
Central Concepts & $\begin{array}{l}\text { Rules, roles } \\
\text { Goals, policies } \\
\text { technology, } \\
\text { environment }\end{array}$ & $\begin{array}{l}\text { Needs, skills, } \\
\text { relationships }\end{array}$ & $\begin{array}{l}\text { Power, } \\
\text { conflict, } \\
\text { competition, } \\
\text { organizational } \\
\text { politics }\end{array}$ & $\begin{array}{l}\text { culture, } \\
\text { ritual, } \\
\text { ceremong, } \\
\text { stories, heroes }\end{array}$
\end{tabular}


Table 1 (continued)

\begin{tabular}{lllll}
\hline Frame & Structural & Human Resource & Political & Symbolic \\
\hline $\begin{array}{l}\text { Image of } \\
\text { Leadership }\end{array}$ & $\begin{array}{l}\text { Social } \\
\text { architecture }\end{array}$ & Empowerment & Advocacy & Inspiration \\
$\begin{array}{l}\text { Basic } \\
\text { leadership } \\
\text { challenge }\end{array}$ & $\begin{array}{l}\text { Attune } \\
\text { structure to } \\
\text { task, } \\
\text { technology, } \\
\text { environment }\end{array}$ & $\begin{array}{l}\text { Align } \\
\text { organizational } \\
\text { and human } \\
\text { needs }\end{array}$ & $\begin{array}{l}\text { Develop } \\
\text { agenda and } \\
\text { power base }\end{array}$ & $\begin{array}{l}\text { Create faith, } \\
\text { beauty, } \\
\text { meaning }\end{array}$ \\
& & & & \\
& & & & \\
\hline
\end{tabular}

Bolman and Deal (2003, p 16)

Research over the past twenty years indicates frame preference does influence leadership effectiveness. Bolman and Deal's (2003) and Bolman and Granell's (1999) research have found that the use of multiple frames was a consistent correlate of effective leadership. Bolman and Deal's studies found that individuals who employ three or more frames are perceived as being more effective leaders than those who consistently use less than three frames (Bolman \& Deal, 1991, 2003). Bensimon, Newumann, and Birnbaum (1989) study reported a correlation between college presidents' increased years of experience and the leadership strategies becoming more refined and multi-framed.

Bolman and Deal's concepts of leadership frames and styles have been widely utilized in many research studies, including dissertation works. Studies of qualitative and quantitative methodologies continue to use the styles/frames as a foundation for research. Bolman and Deals leadership concepts have been the premise for research investigating whole organizations as well as the style(s) of leadership.

Research by Bolman and Deal (1992) established that individual or combined frames were directly correlated with the effectiveness of leaders and that certain frame preference reflects leadership effectiveness. Bolman and Deal (2003) found that the 
effectiveness of the leader is correlated to the number of frames used. The perception of the leader using three or more frames is more effective than those who utilized less than three. The leader who is able to use multiple frames to reframe the situation is best able to analyze the case from several viewpoints and is therefore better able to develop a more holistic approach.

Studies of school administrators found that leaders oriented to the human resource frame are the most predominant (Davis, 1996; Durocher, 1995; Rivers, 1996). In a 1992 study of principals from Singapore and Florida, Bolman and Deal found that American principals used primarily the human resource frame and secondarily the structural frame. Ulmer (2002) found that principal leadership practices in context of state assessment were primarily oriented to the symbolic frame and the structural frame while that of the political frame was utilized the least. In a study using a sample of managers in business and education, Bolman and Deal (1991) found that these leaders were similar in that the images most often utilized were oriented to the structural and the human resource frame. In Cantu's (1997) study of academic deans from 426 public American universities, the human resource frame was the preferred orientation of these leaders followed by the structural, the political, and the symbolic frames. The human resource frame was the prominent orientation in other studies of higher education administrators, as well (Borden, 2000; Miller, 1998; Mosser, 2000; Small, 2002; Turley, 2002). Stankus (2007) reported in studies of the leadership patterns of college presidents, senior administrators in higher education, department chairs, and school district and medical facilities administrators, the leader's use of more than two was rarely found. Mathis (1999) reported in the study of department chairs $32 \%$ used no frame, $11 \%$ used one frame and 
$26 \%$ used all frames. Chang (2004) in his research of the leadership orientation of college of education department chairs found similar results reporting $56.8 \%$ used no frame, $14.8 \%$ utilized one frame, $13.6 \%$ utilized paired frames and $12.5 \%$ used the multiframe orientation.

Research reinforces the belief that leaders operating from a multi-frame leadership orientation perspective are able to view situations as they arise from a holistic approach. However, research indicates that neither the leaders nor their subordinates perceive the overall leadership orientation of the leaders to be multiple-framed (Stankus, 2007).

\section{Bolman and Deal's Four-Frame Model}

Bolman and Deal's four-frame model has been utilized since the early 1990s. The four-frame leadership model was synthesized through a variety of earlier organizational theories. Bolman and Deal's comprehensive theory was created using many of the thoughts and principles of these earlier theories. It is through these frames or lenses that Bolman and Deal refer to multiple perspectives to view organizations. It is through these frames or lenses that an organization or leader may look within and evaluate the whole. The four identified frames include: the structural frame, the human resource frame, the symbolic frame and the political frame. Each frame represents a specific perspective that exhibits its own assumptions and behaviors.

The leader who reflects the characteristics of the structural frame views the world as an orderly state with formal rules and procedures. The leader who utilizes the human resource frame believes that the success or failure of the organization is dependent upon meeting the needs of the individuals within the organization. The leader who reflects the 
perspective of the political frame believes that for the organization to be successful it must accept there will be conflict. Alliances must be built and one must do whatever is necessary to ascertain needed resources. The leader who reflects the perspectives of the symbolic frame embellishes the tradition, culture and the many rituals and symbols within the organization. Leaders may operate from within none of these frames, a single frame, paired-frames or multi-frames (Bolman \& Deal, 2003).

The structural frame. The structural framed leader emphasizes goals and efficiency, formal roles and relationships, creates rules, procedures and hierarchies (Bolman \& Deal, 2003, 2006). These beliefs are founded in behavior theory by including the characteristics of task or initiating structure through directing and clarifying subordinates' roles, problem solving, and criticizing poor work. Structural leadership supports (well-thought-out) roles and relationships, emphasizing data analysis. The structural leader's focus is to assure the bottom line, set clear directions, hold people accountable for results, and attempt to solve organizational problems with new policies and rules or through restructuring.

Bolman and Deal (2003) based the structural frame on the following assumptions:

1. Organizations exist to achieve established goals and objectives.

2. Organizations increase efficiency and enhance performance through a clear division of labor.

3. Appropriate forms of coordination and control ensure that diverse efforts of individuals and units mesh.

4. Organizations work best when rationality prevails over personal preferences and extraneous pressures.

5. Structures must be designed to fit the organizations' circumstances, including their goals, technology, workforce, and environment.

6. Problems and performance gaps arise from structural deficiencies and can be remedied through analysis and restructuring (p. 45). 
The structural view has two main intellectual roots: The works of industrial analysts such as Fredrick Taylor, bent on designing organizations for maximum efficiency and the works of sociologist Max Weber, advocating that "patriarchal organizations" provide maximum efficiency.

Through Taylor's theory of scientific management it was believed productivity could be increased through a specialization of labor. Advocates of Taylor believed breaking down larger tasks into smaller specialized ones could attain greater efficiency.

The structural leader exhibits characteristics that best maximize the productivity and efficiency of their organizations through a definitive structure. They will assign responsibilities to subordinates, develop policies and plans, and create procedures and hierarchies to coordinate activities. Clarity of organizational goals and responsibilities for the subordinates is of the utmost importance. According to Bolman and Deal (2003), this leader succeeds not because of their ability to inspire, but because they have the right design for the times and are able to get their structural changes implemented (p. 352). Effective leaders of this orientation share several characteristics: they do their homework, rethink the relationship between structure, strategy and environment, focus on implementation, experiment, evaluate, and adapt (Bolman \& Deal, 2003).

The human resource frame. Characteristics of leadership oriented to the human resource frame are based upon studies from psychology and organizational behavior. The early works of Frederick Herzbergs' open system organizations, George Homans' work within Western Electric and other organizations found many of the beliefs the human resource frame reflects. Organizations were structured to emphasize employee motivation, employee satisfaction and group morale. Organizations based on human 
relations acknowledged that there exists an informal organization as well as the formal organization within the whole group.

It postulates that people with needs, feelings, and prejudices inhabit organizations. This leader emphasizes the importance of people and relationships. Human resource leaders are passionate about "productivity through people" (Peters \& Waterman, 1982).

Bolman and Deal (2003) base the human resource frame on the following assumptions:

1. Organizations exist to serve human needs rather than the reverse.

2. People and organizations need each other. Organizations need ideas, energy and talent; people need careers, salaries and opportunities.

3. When the fit between the individual and the system is poor, one or both suffer. Individuals will be exploited or will exploit the organization, or both will become victims.

4. A good fit benefit both. Individuals find meaningful and satisfying work and organizations get the talent and energy they need to succeed ( $\mathrm{p} 115)$.

These leaders use a variety of strategies to be successful. They utilize such strategies to involve employees and strengthen the bond between individual and organization. Successful human resource leaders assist the people in fitting into the organization because flexibility is required to meet the needs of the individuals serving the organization. Success typically requires a comprehensive strategy supported by a long-term human resource management philosophy (Bolman \& Deal, 2003).

The political frame. The leader who advocates the political frame views organizations as living, screaming, political arenas that host a complex web of individual and group interests (Bolman \& Deal, 2003). This leader believes that managers and leaders live in a world of conflict and scarce resources. Bolman and Deal (2003) present five propositions to summarize this perspective:

1. Organizations are coalitions of diverse individuals and interest groups.

2. There are enduring differences that exist among coalition members in values, beliefs, information, interests, and perceptions of reality. 
3. Most important decisions involve allocating scarce resources - who gets what.

4. Scarce resources and enduring differences make conflict central to organizational dynamics and underline power as the most important asset.

5. Goals and decisions emerge from bargaining, negotiation, and jockeying for position among competing stakeholders ( $\mathrm{p} 186)$.

This leader understands the competition for resources and is willing to do whatever is necessary to assure the success of the organization. Roots for the political frame can be found in early closed system organizational theory. Early work in the study of organizations not only stressed structure, but also reinforced the concept of organizations as a bureaucracy. When viewing organizations as bureaucratic, one looks for the presence and the strength of the characteristics of a bureaucratic organization as presented in Max Weber's work. “A number of social scientists (Balridge, 1971; French \& Raven, 1959; Kanter, 1977; Pfeffer, 1981, 1992; Russ, 1994) have tried to identify the various wellsprings of power" (Bolman \& Deal, 2003, p 194). These traits that are investigated and analyzed include: a division of labor (specialization): impersonal orientation; hierarchy of authority; rules and regulations (policies); and career orientations. The leader who espouses the political frame understand the landscape and will use the interplay of interests and agendas among different individuals and groups as a constructive vehicle for achieving organizational goals, for building allies and networks. This leader welcomes battle and competition and is willing to use persuasion, negotiation, coercion and compromise to gain control.

The symbolic frame. The leader oriented to the symbolic frame believes that organizations are held together by shared values and culture instead of goals and policies. Culture is often defined as the way we do things around here, both a product and a process. This leader brings imagination, insight, creativity, vision, meaning, and magic 
to the work of leadership. "The frame forms a conceptual umbrella for ideas from a variety of disciplines, including organizational theory, sociology (Selznick, 1957; Blumer, 1969; Clark, 1975; Corwin, 1976; March \& Olsen, 1976; Meyer \& Rowan, 1978; Weick, 1976; Davis and others, 1976; Hofstede, 1984) and political science (Dittmer, 1977; Edelman, 1971)" (Bolman \& Deal, 2003, p 242). Symbols express an organization's culture, the interwoven pattern of beliefs, values, practices and artifacts that define for members who they are and how they are to do things. This leader perceives the organization as a tribe, theater, carnival or culture propelled more by rituals, ceremonies, stories, heroes, and myths than by rules, policies and managerial authority. They look beyond the surface to seek new opportunities. Their focus is not merely on team building, but the creation of a community of believers joined by shared faith and culture.

\section{Superintendent Leadership}

Almost since the first school was created there has been ongoing research focusing on effective schools and leadership. Modern day effective schools research, 1960s to present day, has included three generations of meta-analytic studies. From these three generations of effective schools research there has been created "effective school correlates" (Waters \& Marzano, 2006). These correlates were found to be consistent even when accounting for student background and socio-economic status.

The first generation of studies found these correlations included practices such as: safe and orderly environment, strong instructional leaders, high expectations for student achievement, clear and focused mission, and time on task. Leaderships' influence on student achievement was focused at the classroom level, the teacher. While it was argued 
the leadership of the principal influenced many of these correlates, the investigations of this first generation studies did not go beyond the classroom setting.

In the second generation of effective schools research, investigators continued to examine the relationships between classroom practices, school practices and student achievement. "In this generation researchers were able to more explicitly describe effective practices and compute the effective sizes, or strength of relationship, between specific practices and student achievement” (Waters \& Marzano, 2006, p 5). This generation provided not only more quantitative data for analysis, but looked at schools and their effect on student achievement beyond the classroom setting.

"Third generation of effective schools research translates well-defined, effective classroom, school, and leadership practices into specific actions and behaviors" (Waters \& Marzano, 2006, p5). This generation of research that focuses on the building level leadership concluded that: (1) principal leadership does have an effect on average student achievement; (2) specific leadership responsibilities correlates to student achievement; (3) there are specific practices of principals for fulfilling leadership responsibilities; and (4) certain behaviors of the principal leadership does have a positive effect on student achievement. This third generation of research did not only go beyond the influence of leadership at the building level, but did begin investigating the influence of the leadership outside the classroom.

There is now a fourth generation of effective schools research that has gone beyond the building level and investigates the influence of leadership by the superintendent and central office administrators on student achievement. One such study is the work of Waters and Marzano (2006) entitled "School Leadership That Works." 
While this fourth generation does support the assertion that not all superintendent behaviors produce a positive impact on student achievement, the findings do indicate that when district leaders effectively address specific responsibilities, they can have a profound and positive impact (Waters \& Marzano, 2006). These findings are contrary to past Secretary of Education William Bennett's reference to the "blob" of education, that "he argued, is made up of people in the education system who work outside the classroom, soaking up resources and resisting reform without contributing to student achievements" (Education Week, March 2, 1987).

In their fourth generation of effective schools research, a meta-analysis study, Waters and Marzano (2006) concluded: 1) there exists a correlation between district leadership and student achievement; 2) the leadership's responsibilities: a. goal setting process; b. non-negotiable goals for achievement and instruction; c. board of education alignment with and support of goals; d. monitoring of the goals for achievement and instruction; and e. the use of resources to support the goals for achievement and instruction were found to be significantly correlated to student achievement; 3 ) the practice of site-based management was not significantly correlated to student achievement; and 4) the longevity of the superintendent has a positive effect on the average academic achievement of students in the district. In sum, the longer the superintendent remains in the district, the more likely he will be able to implement inclusive goal-setting processes that result in board adopted "non-negotiable" goals for achievement and instruction. He who assures that schools align their use of district resources for professional development with district goals and who monitors and evaluates progress toward goal achievement is fulfilling responsibilities correlated with 
high levels of achievement. This impact of leadership was found through the correlation of district level leadership with student achievement. The range of this effect was found to be large. A variance Waters and Marzano termed the "differential impact" of leadership.

In "Primacy of Superintendent Leadership" (2007), Waters and Marzano concluded that superintendents who embellished beliefs, that for change and improvement to be substantial and sustainable it must be systemic, had a positive influence on student achievement. When these beliefs are shared by all the stakeholders, individuals take on responsibilities district-wide. In these districts student achievement was found to be significantly higher than in districts where the superintendent espoused the belief that goals for students achievement need to aggregate up from individual schools. It was found, in districts where professional development builds knowledge and skills, that requires teachers and principals to implement the district-wide instructional program, where ongoing assessments using formative and observational adjustments were implemented, increasing student achievement occurs.

In "Leadership that Sparks Learning” (2006) Waters, Marzano and McNulty concluded that, effective school leadership can substantially boost student achievement. This finding was based on an analysis of 5000 studies that purported to examine the effect of leadership on student achievement. The authors designate between first-order and second-order change for student achievement. First-order changes build on past and existing models where second-order changes dramatically break with the past and challenge existing models, norms and values. The author's findings indicate that how a 
leader addresses their goals for instruction and achievement, first-order change verses second-order change, is statistically correlated to higher student achievement.

In summary, literature on leadership has evolved from three to four generations of effective schools research. The research has evolved from focusing on the influence of leadership at the classroom teacher level to that of the superintendent and central office staff. The most recent research focuses on the leadership influence of the central office staff and the superintendent and indicates a positive effect on student achievement.

\section{School Funding}

One can find three issues common to school funding research and school finance litigation. Does the system a state utilizes for the funding of public education: (1) provide an adequate amount of resources to educate a child; (2) provide the resources in an equitable manner statewide; and (3) does this adequate and equitable system provide a thorough and efficient education?

Pan et al (2004) found that one size does not fit all. The resources necessary to provide an adequate education to all children are not the same. Baker (2005) reviewed empirical methods of measuring adequacy. It is his belief that if more studies of this type were done nationwide, insights to provide more appropriate adequacy levels could be established. He contended that studies such as his that are used to identify current policies that shape education adequacy are necessary. We must understand that all children can learn, but all children do not learn the same way. He addressed steps that state legislatures can take to provide adequacy with the understanding of the additional costs associated with different children under different socio-economic and cultural environments. 
Greene and Trivitt (2008) investigated the effects of the rulings of judges dealing with school finance on student achievement. The results found were similar to the effects of legislative decisions on these matters. There appears to be no effect that may indicate judges and legislators are specialists in reforming school finance issues. This is not surprising, for as Greene and Trivitt (2008) state, "Education reform, on the other hand, involves complicated technical questions - something for which judges and judicial procedures are not particularly well suited" (p 226).

Ammar et al (2005) define the fiscal condition of a school district as the ability to finance educational services to assure adequate resources for student performance over the long run without temporary disruption of services. The purpose of their research was to identify financial condition indicators to provide a warning system for school administrators of future poor fiscal conditions. They argue future poor fiscal conditions can be avoided through good fiscal predictability and stability practices. They also state, "During economic downturns aid-dependent districts can be faced with large losses of state revenue or property tax increases" ( $\mathrm{p}$ 239). This experience has been too common to districts across Ohio through the experience of the boom and bust funding cycles of the present unconstitutional funding system. Ammar et al (2005) case study stressed the importance of predictability and stability of school funding, especially among low poverty, high state aid districts.

Roza and Miles (2002) found that present day reform movements to fix school funding problems often focused on equalization of revenues and expenditures statewide. Few modern day reforms address the discrepancies in expenditures locally and statewide. They looked at spending patterns horizontally and vertically. For example, do students 
with similar characteristics receive equal resources (horizontal spending practices)? And do students with dissimilar characteristics receive appropriately dissimilar resources (vertical spending patterns)? This analysis discovers deep inequities horizontally and vertically when focusing on equalizing revenues and expenditures. Many of the resources available found their way to the more favorable schools. All was not equal.

Hirth and Eiler (2005) also completed a study examining the horizontal and vertical equity of general fund distribution formulas. It is through those formulas that adequate and equitable tests were applied. They also found great inequities in these systems.

Roza and Miles (2002) found that in school litigation cases, lawyers argue that disparities resulting from expenditure differences violate state guarantees to equal access to a quality education. In reality, as Card and Payne (2002) state, they "similarly found that when school finance systems are struck down by courts, the variation in per pupil spending within states is reduced" ( $\mathrm{p} 228$ ). While many of the issues of litigation surround tests of equity and adequacy and fixes to these issues surface soon after courts make decisions in favor of school districts, we continue to struggle in determining what is thorough and efficient.

Reschovsky and Imazdki (2000) in their study of the approaches to the funding of state public education noted that some of the approaches addressed factors affecting discrepancies in expenditures outside of local control. Factors they identified included: some districts are forced to offer higher salaries to attract and retain qualified teachers, land costs, and attractiveness of the geographic area (i.e. weather and crime rates). Some 
districts must hire more teachers and spend more on non-teacher related resources to provide their students with an adequate education.

Fowler and Monk (2001) found that unless approaches to fund public education recognize that geographic and quality of education results in a difference in expenditure costs; locally, regionally, and across the state, systems cannot be equitable. In their study, they found that within large individual districts, discrepancies in expenditures could be large between schools. An example they presented is that often the more experienced and qualified teachers (higher paid) migrate to more favorable schools within districts or to other districts statewide, creating large inequities.

Greene (2005) assessed the impact of real resource allocations decisions on student outcomes. Those are the personnel and material resources to increase student learning. The study used the production function approach with generally accepted multiple regression and correlative techniques. From this study, it is recognized that real resources make a difference in student outcomes. Not all students have access to the same resources. This study identifies some of the specific factors that contribute to discrepancies in expenditures.

Roza and Miles (2002) identified large discrepancies in expenditures in high poverty, low achieving schools. They identified these as schools where it was difficult to recruit and retain highly qualified staff. Teachers would tend to leave these areas to more desirable ones. DeAngelis and Presley (2007) found in a study of teachers leaving the profession that teacher attrition across the state of Illinois was relatively the same regardless of school types. Often academically strong teachers recruited to disadvantaged schools were more likely to leave as the result of poor working and learning conditions. 
It may be argued that the challenges that face schools today are greater than any time in history and the fact that student achievement has remained unchanged is actually an accomplishment. Green and Trivitt (2008) state in their findings, “... we find no evidence to suggest that student learning improves as the result of court-ordered changes in the school finance system" (p 226). "Today, school finance analysts must understand how effective educational systems operate" (Odden, 2001, p 90).

Simply finding enough money to adequately fund the system of public education within a state does not solve the school finance problem. An equally difficult challenge is structuring a finance system to support research-based resource allocation strategies (Odden \& Picus, 2007, p 4).

\section{School Size}

Current research appears to be quite mixed on the effect of school size regarding student performance. It would appear that smaller schools better serve rural communities and students from lower socio-economic status, while larger schools may better serve the more affluent students. Interesting to note in the literature is that larger schools today are experiencing greater student achievement through the formation of schools within the schools, or smaller learning communities.

Howley et al (1989) found that little if any challenges were made questioning the effectiveness of larger schools until the 1960s. Prior to the publication of Big School, Small School: High School Size and Student Behavior by Roger Barker and Paul Gump and research findings that questioned the effectiveness of the larger schools school size, the influence of school size had not been questioned. Howley found that students felt safer, were involved in more activities, and overall were more satisfied with smaller 
schools. The foundation built upon the ideas that larger schools could offer a more rigorous, wider and better curriculum for less money and better serve the needs of the students was no longer assumed.

Barker (1986) concluded from the research that school size by itself is not the sole determining factor for students' achievement, but concluded a student-centered focus was found to be the inherent characteristic to student achievement. Barker (1986) indicated that smaller schools had greater involvement by the community, parents and students, creating a greater feeling of belonging and leading to greater student achievement. Huang and Howley (1993) also determined that students from lower socio-economic areas had greater achievement in the smaller schools where relationships between all the stakeholders were closer. Howley (1994) concluded that the students from higher socioeconomic status were less likely to be affected by school size, concluding that the most effective school size is dependent upon the community it serves. Johnson, Howley and Howleys' (2002) research indicated the effectiveness of size on student achievement was very weak in affluent settings and comparatively strong in impoverished areas.

The National Office for Research, Measurement and Evaluation Systems (NORMES) in The Geographic Academic Policy Series (GAPS) at the University of Arkansas found that there is no specific trend between school size and performance above or below the state average for either literacy or mathematics across the three years of data collection $(2003-2005)$.

Muir (2001) identified three issues associated with school size and student achievement: 1) networking between students, parents and teachers; 2) costs associated with schools of different size; and 3) long-term social benefits for students. Muir's 
research indicated that schools of smaller size are most beneficial for maximizing student achievement. Muir stated seven reasons why small schools work best:

1. Governance. Teachers are better able to meet and communicate with one another.

2. Respect. A greater mutual respect exists among students and teachers because of closer personal relationships.

3. Simplicity. Less bureaucracy leads to individualization for both teachers and students.

4. Safety. Anonymity breeds contempt and anger; in a small school, strangers are easily spotted.

5. Parent Involvement. More natural opportunity can be found to build alliances between parents, teachers, and students.

6. Accountability. A greater level of peer accountability is created, and consequently, more concern regarding public character.

7. Belonging. Every student is known and relationships are stronger (p 43).

Viadero (2001) found that smaller schools have better attendance rates, lower dropout rates, and higher grades. Howley and Gunns' research (2003) maintained that superintendents need to sustain small high schools in their districts especially in rural settings. Research on high school size conducted in the past thirty years suggests a need for smaller schools (Gregory, 2000). However, despite rising support for smaller schools, high schools have continued to grow in size. Sizer (1996) indicated that this may be the result of the multifaceted responsibility high schools serve in their community. The high school is one of the few entities that bring the community together and serves as more than just a place of learning. 
In summary, the research would indicate that bigger is not necessarily better. Most recently, Governor Ted Strickland (Ohio) has commissioned through recent legislation a committee to study the benefits of the consolidation of governmental entities, including schools. Governor Strickland, a proponent of public education must realize that while research indicates larger schools can deliver a wider curriculum, offer more class offerings and produce a lower cost per pupil, larger schools do not guarantee higher student achievement. If anything, the research is clear in that to maximize student achievement, the best size of schools needs to be decided by the community it serves.

\section{Socio-economic Conditions}

Current research indicates there are many factors correlated to student achievement, but none may be as strong as the socio-economic status of students. With the enactment of the No Child Left Behind Act, there is an increasing concern of the effectiveness of schools to educate all children. "Increasingly, we are recognizing that questions with regard to educational equity must focus on the distribution of important learning conditions in schools and that equity cannot be addressed in the absence of references to educational outcomes disaggregated by student race, gender and economic status" (Murphy, 2001, p145).

Today research directs attention to variables that are correlated to student outcomes through access to educational opportunities. These variables can be classified as alterable variables and unalterable variables. Alterable variables are those that may be manipulated by school personnel, including instructional time or instructional strategies. Unalterable are those that are found to help explain student learning but are not subject to control by school personnel. These student factors include race, gender and socio- 
economic status. Due to this concern over the distribution of alterable educational resources and school processes, a third-generation of equity issues has emerged. This third-generation of equity issues does not propose: (1) fiscally neutral state finance systems, or (2) categorical funding programs to offset the higher cost to educate selected groups. Murphy, Hallinger and Lotto (1986) listed the treatment differentials among instructional groups and curricular tracts: patterns of discrimination in lower ability groups in their research (see Table 2).

Table 2

Treatment Differentials among Groups and Curricular Tracks: Patterns of Discrimination in Lower Ability Groups

INSTRUCTION

receive least prepared teachers teachers feel less comfortable teaching teachers are less knowledgeable about how to teach teachers spend less time preparing teachers hold lower performance expectations for themselves more likely to receive instruction from aides

negative and inappropriate performance expectations for students objectives less like to be explained materials introduced less clearly less time spent on introductory learning activities

less interactive teaching; more worksheets less teacher clarity in presentations more chaotic learning structure greater confusion as to appropriate modes of student participation fewer work standards provided students held less accountable for work content less academically oriented

personal and social goals more important than academic objectives

blurred academic content use of "relevant" subject matter lack of clear purpose and focus to classroom activities emphasis on therapy rather than learning fewer task-related interchanges between teachers and students material covered at slower pace lower-level objectives and functional skills emphasized

fewer academic courses completed fewer academic standards specified fewer reports and projects assigned fewer homework assignments less academic feedback fewer tests given little emphasis on skill progression less sequenced and integrated work in individual classes 
Table 2 (continued)

\begin{tabular}{ll}
\hline INSTRUCTION & CURRICULUM CONTENT \\
$\begin{array}{ll}\text { reduced quality of teacher-student } \\
\begin{array}{l}\text { interactions } \\
\text { less teacher enthusiasm and warmth }\end{array}\end{array}$ & $\begin{array}{c}\text { more half-year courses } \\
\text { fewer sequenced and integrated courses } \\
\text { across years } \\
\text { strong behavioral aspect to academic } \\
\text { functions }\end{array}$ \\
$\begin{array}{ll}\text { TIME } \\
\text { instruction begins later in the class period } \\
\text { more instructional time lost during } \\
\text { transitions }\end{array}$ & $\begin{array}{l}\text { less counseling about appropriate course } \\
\text { work to take }\end{array}$ \\
$\begin{array}{ll}\text { more time spent with no work assignment } \\
\text { more time lost due to student interruptions } \\
\text { more time lost due to teacher interruptions } \\
\text { disproportionate amounts of instructional } \\
\text { time spent in controlling and managing } \\
\text { behavior }\end{array}$ & $\begin{array}{l}\text { SUCCESS } \\
\text { more off-task behavior } \\
\text { more class time devoted to homework } \\
\text { more off-task behavior } \\
\text { instruction ends earlier in the period }\end{array}$ \\
\hline
\end{tabular}

Source: Murphy, Hallinger, \& Lotto (1986), pp. 22-23.

It is argued that wealth, which is an indicator of financial and human capital, can affect student achievement and also is a variable that can help explain the gap in test scores amongst socio-economic groups. Orr (2003) stated, "While researchers have paid extensive attention to socio-economic status as a determinant of achievement, wealth is often not included in conceptualizations of this factor" ( $p$ 201). Research has found wealth has significant effects on many academic outcomes, including education attainment, probability of dropping out, risk of expulsion, risk to hold back as well as aspirations. Orr concluded without considering family wealth, we are overlooking how wealth has a positive effect on achievement even when socio-economic status is held constant. Jehlen (2000) reported black children don't do as well in school as white children with similar socio-economic status because the wealth levels can be so different. 
However, when wealth levels are similar, black students are more likely to graduate than whites. Furthermore Jehlen (2000) found, add parental education to the wealth factor and you have an indicator that can predict the probability of educational success. Greene, Huerta and Richards (2007) found, although socio-economic status remains the greatest predictor of college aspirations, resource quality as measured by the percentage of faculty with master's and doctoral degrees is not far behind.

Cavanaugh (2007) reported in Poverty's Effect on U.S. Scores Greater Than for Other Nations, "The exams results are not surprising; given research showing that the U.S. system tends to provide under-privileged students with less demanding curricula, poorer-quality teachers and few educational resources than their peers in wealthier U.S. communities" ( $p$ 3). This is most interesting when compared with other nations whose findings are more definite than within the U.S.

In a case study by Ammar et al (2005) cost factors in education outside of district control were identified that include resource prices, proportion of district students living in poverty or requiring special services, and student density or sparsity. These are factors that require greater resources to enable students to reach proficient levels of achievement.

The National Office for Research, Measurement and Evaluation Systems (NORMES) in The Geographic Academic Policy Series (GAPS) at the University of Arkansas found that for both literacy and mathematics, districts, with more than $67 \%$ of their students participating in the free and reduced lunch program (FRLP), are more likely to have student performance below the state average over a three-year period (2003 $-2005)$. 


\section{Locale}

Much research has been done studying the relationship between district locale and student performance and the findings vary considerably. With state and federal governments acknowledging that rural and metropolitan districts need support to meet the achievement levels established by the No Child Left Behind Act, legislatures have enacted laws to address the needs of rural and metropolitan locales. Arnold, Biscoe, Farmer, Robertson and Shapley (2007) found, as result of these actions, how the government defines locale has implications for education policies and practices. Congress has metro-centric locale codes and other criteria to determine eligibility for two of their rural achievement program initiatives. The "Rural School Achievement Program" provides initiatives to help rural locales meet Adequate Yearly Progress. One of the major issues in the classification of locales is diversity and change that is occurring nationally, regionally and locally (Arnold et al. 2007).

Campbell and Silver (1999) found that deficits occurred in rural locale that included: lack of varied curriculum, lower test scores and higher dropout rates. Roscigno and Crowley (2001) concluded students living in rural areas exhibit lower levels of educational achievement and have a higher likelihood of dropping out of high school than non-rural students.

More recent research would appear to indicate achievement in rural areas as not so problematic. Howley and Gunn (2003) concluded, "On the basis of nearly 25 years of NAEP data, there is little evidence for the claim that rural mathematics achievement is deficient” ( $p$ 89). Winters (2003) found in Tennessee, that on three different test instruments, rural students actually outscored non-rural students. 
It is evident that more research is necessary to investigate the effects of locale on student performance.

\section{Per Pupil Expenditure}

Research on the relationship between per pupil expenditure and student achievement varies considerably.

Brorsen and Jacques (2000) found money spent on instruction led to an increase in student performance within the state of Oklahoma. They concluded should schools spend more money and the goal is to increase student test scores, the money should be spent on teachers, teacher supplies and teacher training. A negative effect was found in districts that expended dollars to counseling and administrative services. Spending is useful when targeted to instruction.

Odden (1994) found, "Yet, while education spending goes up, average student achievement does not" ( $\mathrm{p}$ 104). The trend continues as evident in the research of Greene and Trivitt (2003) as they state, "Overall the last three decades student achievement has remained essentially unchanged in the United States, but not for a lack of spending" ( $p$ 224).

The National Office for Research, Measurement and Evaluation Systems (NORMES) in The Geographic Academic Policy Series (GAPS) at the University of Arkansas found in 2004, that a larger percentage of students from districts spending more than the state average expenditure per pupil were performing lower than the state average on test scores in literacy and math than in 2003. Without the availability of 2005 data, this finding could not be identified as a trend. If determined a trend, the argument that increased per pupil expenditures results in higher student achievement could be disputed. 
Skandera and Sousa (2002) reported between 1970 and 1995, per-pupil expenditures increased by more than 75 percent. During that time period, the pupilteacher ratio decreased by 25 percent, the percentage of teachers with advanced degrees doubled, and median teacher experience nearly doubled. With more teachers in the system, and with teacher pay linked to increases in credentials and experience, higher per-pupil spending resulted. Furthermore, between the 1969-70 and 1995-96 school years, "administration expenditures" increased by more than 80 percent and "other school services" accounted for nearly 18 percent of total public education expenditures. This is an increase of almost 200 percent. The American Legislative Exchange Council's (ALEC) "Report Card on American Education, a State-by-State Analysis 1981-2003," (2004) concluded:

It is clear after studying the data and results that the policies of the past have failed to meet the educational needs of our country's children. If we continue to spend more money on the existing educational system in an attempt to buy our way to better student achievement, we will condemn another generation of students to mediocrity (p. 130).

The ALEC study showed no correlation between conventional measures of educational inputs (such as expenditures per pupil and teacher salaries) and educational outputs (such as scores on standardized tests). Simply stated, increased funding does not translate into improved achievement. 


\section{Summary}

Chapter 2 has researched literature relative to the variables of this study. After this review, many of the variables of this study have been investigated in the past separately or in groupings not similar to those presented in this study. The findings of these relationships vary considerably; hence, the necessity to investigate the relationships of leadership styles and fiscal conditions with student performance could not be timelier. 


\section{CHAPTER 3}

\section{Methodology}

This research examined the relationships of the leadership styles of superintendents and fiscal conditions with district student performance in school districts across Ohio. Control variables utilized in this study include: superintendent gender, district size, district socio-economic status, district locale and district expenditure per pupil. This chapter is structured in seven sections: research design, population/participants, instrumentation, procedure, data analysis, confidentiality and anonymity, and summary.

\section{Research Design}

This research investigated the relationships of the study variables: district student performance, superintendent leadership styles, district fiscal conditions- sustainability, district fiscal condition-predictability, superintendents' gender, district size, district socio-economic status, district locale and district per pupil expenditure. To determine the relationships of superintendent leadership styles, fiscal conditions, superintendents' gender, district size, district socio-economic status, district locale, and actual per pupil expenditure on district student performance across the state of Ohio, the superintendents' leadership style was initially identified. Secondly, the fiscal conditions (predictability and sustainability) of the respective school districts were calculated. Lastly, the control variables: district size, district socio-economic status, district locale, and district per pupil expenditure were determined.

According to previous research (Bensimon, 1989; Cantu, 1997; Bowen, 2004; Chang, 2004; Mathis, 1999; Mosser, 2000; Small, 2002; Stankus, 2007), leadership styles 
vary through the individuals' utilization of the Bolman and Deal's leadership frames. In this study, the relationships of the leadership styles of the superintendents and the fiscal conditions (predictability and sustainability) of a school district with district student performance will be examined. Control variables; district size, district socio-economic status, district locale and district per pupil expenditure along with the personal trait gender were utilized as covariates.

The variables district student performance, fiscal condition-sustainability, fiscal condition-predictability, district size, district socio-economic status, and districts per pupil expenditure will be placed on continuums for the analysis of this study. The variables leadership style, district locale and gender were categorized. Where possible the use of continuous variables were utilized to provide more information and to not reduce variability of the study.

\section{Population/Participants}

The population of this study was qualifying superintendents from the 614 public schools across Ohio from the 2007-08 school year. The names and e-mail contacts for the superintendents serving the school districts across Ohio during the 2008-09 school year were provided by the Buckeye Association of School Administrators (BASA).

To qualify to be a participant, the 2008-09 school year must represent at a minimum, the sixth year of continuous service by the superintendent in their present district. It is the researcher's belief that a superintendent needs to be in the school district a minimum of five continuous years to be able to have an influence the district student performance. Superintendents that the 2008-09 school year reflects five or fewer years 
serving their district will not meet the requirement of the primary analysis but will be utilized in an analysis of an inclusive list.

\section{Instrumentation}

The research used the Bolman \& Deal's: Leadership Orientations: Self instrument (Appendix B). At the completion of the survey instrument, the superintendents were requested to list the number of years they have served their present district, the district they are serving and their gender.

\section{The Leadership Orientations (Self) Instrument}

Introduced in 1990 by Lee Bolman \& Terry Deal, two parallel versions of leadership orientations instruments, others and self were developed. These survey instruments measure the leaders' orientations toward leading through each of the four frames. For this study the version of the Bolman \& Deal instrument labeled "self" was utilized. The "self" instrument of self-evaluation was completed by the qualifying superintendents. This version consists of three sections. The first section contains rating scales and the items were used to determine the frame that the superintendent exemplified. Eight items represent each of the four frames of leadership. The items are in a consistent frame sequence: structural (item 1, 5, 9, 13, 17, 21, 25, 29), human resource (items 2, 6, 10, 14, 18, 22, 26, 30), political (items 3, 7, 11, 15, 19, 23, 27, 31), and symbolic (items $4,8,12,16,20,24,28,32$ ). The second section contains six forcedchoice items. The options under each item are arranged in the same sequence as the first section. The last section has two one-item measures: effectiveness as a manager and effectiveness as a leader. Respondents used a five-point Likert scale to rate the degree to which they exhibit each leader behavior $(1=$ Never, $2=$ Occasionally, $3=$ Sometimes, 
4=Often, and 5=Always). A superintendent with a mean score on the questions of a section equal to or above 4.0 is classified as championing that leadership frame.

Research has generally found that the validity of self-rating is generally low (Bolman \& Deal, 1990). The validity of the Leadership Orientations (Self) surveys were established and reported by authors in an unpublished paper in 1990. With regard to the reliability, the statistics for Leadership Orientations on the basis of 1309 colleague ratings for a multi-sector sample of managers in business and education reported on Lee Bolman's web page (http://www.leebolman.com/index.htm), entitled as Potential Users of Leadership Orientations Instruments, show that the split-half correlations for four frames is beyond 0.8, the Spearman-Brown coefficient, and Buttman (Rulon) coefficient exceed 0.9. The Leadership Orientations (Self) survey instrument has been used in numerous studies (Bensimon, 1989; Bolman \& Deal, 1991; Bowen, 2004; Chang, 2004; Crist, 1999; Mathis, 1999; Mosser, 2000; Small, 2002). Table 3 indicates the Structure of the Bolman and Deal Leadership (SELF) Survey (see Table 3).

Table 3

The Structure of the Bolman \& Deal Leadership Orientations (Self) Survey

\begin{tabular}{lll}
\hline Survey Section and Frame & $\begin{array}{l}\text { Reliability } \\
\text { (Coefficient Alpha) }\end{array}$ & $\begin{array}{l}\text { Number of Peers Reliability } \\
\text { Coefficients Reported }\end{array}$ \\
\hline Section I: & & \\
Structural frame & $r=.920$ & 1,309 \\
Human resource frame & $r=.931$ & 1,331 \\
Political frame & $r=.913$ & 1,268 \\
Symbolic frame & $r=.931$ & 1,315 \\
Section II: & & \\
Structural Frame & $r=.841$ & 1,229 \\
Human resource frame & $\mathrm{r}=.843$ & 1,233 \\
Political Frame & $r=.799$ & 1,218 \\
Symbolic Frame & $r=.842$ & 1,221
\end{tabular}

From Bolman, L. (2001). http://www.leebolman.com/orientations.htm 
Letter for permission to use the Leadership Orientations (SELF) instrument is located in Appendix C.

\section{Procedure}

This research utilized the self-report survey instrument with a procedure in place to collect data electronically.

The qualifying participant's names from the 614 public school districts were invited to participate in the study. A letter to invite the selected superintendents to participate in the study was sent via e-mail. The letter provided a link to a website to complete and submit the survey. (Appendix D). In the e-mail was an introduction letter describing the importance of the research, inviting them to participate by submitting the survey. They were instructed to complete the "Leadership Orientations (Self)" survey instrument along with requested personal information and return it electronically.

Each participant was prompted to respond within a two week period. A follow-up e-mail (Appendix E), along with instructions was sent to those who did not respond within the two week period to further entice them to participate.

\section{Data Analysis}

\section{Statistical Computations}

The Statistical Analysis System (SAS) or SPSS was used for the statistical computations. Descriptive statistics and linear multiple regression models were utilized to report findings from the study.

For this study multiple regression models were utilized to determine whether our variables are related to determine the degree to which they are. This analysis provides a significant model as a whole with a 0.05 alpha level of significance. The R-Squared 
value shows the strength model in investigating the association of the independent variables with the dependent variable as a whole. The significance of each independent variable was determined. Lastly, the beta weights shown in the model provide the relative strength of the association of each independent variable.

A bi-variate correlation matrix was completed to investigate the influence of the variables on one another.

A multi-collinearity diagnostic was also completed in SPSS to determine if the independent variables per pupil expenditure and fiscal condition-sustainability are too similar to be utilized in the study. If they would have been found to be too similar, one of the variables could have been removed or a composite variable could have been created.

\section{Research Questions}

Question 1: What are the leadership styles (as measured by the four frames) of the participating superintendents across Ohio?

The Bolman and Deal's Leadership Orientations (Self) was utilized to collect data regarding question one. The overall mean and standard deviation of each frame was computed as well as the mean of each leadership frame individually. A superintendent whose mean score self-reported is 4.0 or above on the 5-point Likert scale will be considered to be espousing that frame. The overall mean, standard deviation by the four frames, and the number of the respondents who were using each of the four frames was reported. Frequencies and percentage of the superintendents who utilize various patterns of none, single, paired, and multi-frame was also identified and reported.

Question 2: In consideration of appropriate control variables, what are the individual and combined relationships of superintendents' gender, district size, district socio-economic 
status, locale, per pupil expenditures, district fiscal condition - sustainability and district fiscal condition - predictability with superintendents' leadership styles?

To examine Research Question 2, the analysis on individual and combined relationships of superintendents' gender, district size, district socio-economic status, locale, per pupil expenditures, district fiscal condition - sustainability and district fiscal condition - predictability with superintendents' leadership styles was through a linear regression model. In the regression equation the leadership style served as the criterion variable. The overall means and standard deviations by superintendents' gender, school size, socio-economic status locale, per pupil expenditure and district fiscal condition sustainability and district fiscal condition - predictability is reported.

Question 3: In consideration of appropriate control variables, what are the individual and combined relationships of superintendents' gender, district size, district socio-economic status, locale, per pupil expenditures, leadership style and district fiscal condition predictability with the district fiscal condition - sustainability?

To examine Research Question 3, the analysis on individual and combined relationships of superintendents' gender, district size, district socio-economic status, locale, per pupil expenditures, leadership style and district fiscal condition - predictability with district fiscal condition - sustainability was through a linear regression model. In the regression equation district fiscal condition - sustainability serves as the criterion variable. The overall means and standard deviations by superintendents' gender, school size, socio-economic status, per pupil expenditure and district fiscal condition predictability is reported. 
Question 4: In consideration of appropriate control variables, what are the individual and combined relationships of superintendents' gender, district size, district socio-economic status, locale, per pupil expenditures and district fiscal condition - sustainability with the district fiscal condition - predictability?

To examine Research Question 4, the analysis on individual and combined relationships of superintendents' gender, district size, district socio-economic status, locale, per pupil expenditures and district fiscal condition - sustainability with district fiscal condition - predictability was through a linear regression model. In the regression equation district fiscal condition - predictability serves as the criterion variable. The overall means and standard deviations by superintendents' gender, school size, socioeconomic status, per pupil expenditure and district fiscal condition - sustainability is reported

Question 5: In consideration of appropriate control variables, what are the individual and combined relationships of superintendents' gender, district-level fiscal condition sustainability, district-level fiscal condition - predictability, and superintendents' leadership style with district student performance?

To examine Research Question 5, the analysis on individual and combined relationships of superintendents' gender, district fiscal condition - sustainability, district fiscal condition - predictability and superintendents' leadership style with district student performance was through a linear regression model. In the regression equation district student performance served as the criterion variable. The overall means and standard deviations by superintendents' gender, district fiscal condition - sustainability, district fiscal condition - predictability and superintendents' leadership style is reported. 
The following represents the study variables abbreviations and the variable they represent. The table also presents the type of variable represented (see Table 4).

Table 4

Study Variables Abbreviations - Type

\begin{tabular}{lll}
\hline Abbreviation & Study Variable Represented & Type \\
DSP & District Student Performance & Continuous \\
SLS & Superintendent Leadership Style & Categorical \\
FCP & Fiscal Condition Predictability & Continuous \\
FCS & Fiscal Condition Sustainability & Continuous \\
SDS & School District Size & Continuous \\
DSS & District Socio-Economic Status & Continuous \\
SDL & School District Locale & Categorical \\
DEP & District Expenditure Per Pupil & Continuous \\
GEN & Gender & Categorical \\
\hline
\end{tabular}

Presented below is an example of data table for the study variables (see Table 5).

Table 5

Data Set utilized for the study

\begin{tabular}{lccccccccc}
\hline & & \multicolumn{8}{c}{ Study Variable } \\
School District & DSP & SLS & FCP & FCS & SDS & DSS & SDL & DEP & GEN \\
\hline Ada Expt. Village & 93.5 & 3 & .5561 & .0653 & 829 & .2810 & 2 & $\$ 7,881$ & 2 \\
& & & & & & & & & \\
$\begin{array}{l}\text { Adam County/Ohio } \\
\text { Valley Local }\end{array}$ & 93.2 & & .5525 & .0701 & 4020 & .2770 & 3 & $\$ 9,265$ \\
Adena Local & 92 & & .7012 & .0921 & 1206 & .2770 & 3 & $\$ 8,117$ \\
Akron City & 83.7 & & .5255 & .0567 & 25758 & .7874 & 1 & $\$ 10,421$
\end{tabular}


Table 5 (continued)

\begin{tabular}{llllllllll}
\hline & \multicolumn{8}{c}{ Study Variable } \\
School District & DSP & SLS & FCP & FCS & SDS & DSS & SDL & DEP & GEN \\
\hline Alexander Local & 92.1 & .6351 & .0629 & .0773 & 1641 & .4410 & 3 & $\$ 8,907$ \\
& & & & & & & & \\
Allen East Local & 95.8 & .6644 & .0508 & .0508 & 956 & .1830 & 3 & $\$ 7,658$ \\
\hline
\end{tabular}

\section{Confidentiality and Anonymity}

This study was dependent upon responses from human subjects and requires their voluntary participation. Their anonymity and confidentiality was protected consistent with the Institutional Review Board (IRB) standards and policies. In the cover letter, the subjects were provided with information such as the purpose of the research, a comment that participation is voluntary, the right to not respond to every item, and the assurance of confidentiality and anonymity. Participant codes were assigned to protect the identity of each of the respondents. Cover letters are included in appendices and are labeled accordingly: cover letter to superintendents (Appendix D) and a cover letter second mailing (Appendix E). Survey responses were coded with numbers for subsequent use and all identities were kept confidential. Approval by the West Virginia University Institutional Review Board for the Protection of Human Subjects is also documented in Appendix F.

\section{Summary}

In this chapter, the methods used to examine the relationships of superintendent leadership styles and gender, district fiscal condition-sustainability, fiscal conditionpredictability, district size, district socio-economic status, district locale, district per pupil expenditure and district student performance across the state of Ohio were presented. For this study superintendent leadership style, fiscal condition-sustainability, fiscal condition- 
predictability, and district student performance will be in-depth variables. The Bolman and Deal's Leadership Orientation (Self) was utilized to provide data necessary to answer the five research questions. In addition, the superintendents were asked to provide personal information including: years of experience in their present position and their gender. An introductory letter with the link to submit the survey instrument was e-mailed to all superintendents serving in the 614 public school districts in Ohio. The SPSS system was used for statistical computations to analyze the data. An alpha level of .05 was the criterion level of significance for this study. The results of the data analysis will be presented in Chapter 4. 


\section{Chapter 4}

\section{Results}

This chapter presents the results of the survey responses investigating the relationships of the leadership styles of superintendents, district fiscal conditions (sustainability and predictability) and district student performance.

The first section contains the demographic information for the superintendents who responded to the surveys that were complete and identifiable. An inclusive list of all of the respondents as well as a list of those qualifying will also be presented. The second section will present the descriptive statistics for the variables utilized in study. The third section will present the findings of the bi-variate correlation matrices. The fourth section will discuss the method of the multiple regression model utilized within the study. The fifth section will present the analysis of the data within the framework of the five (5) research questions. The sixth section is an ancillary analysis unwrapping the relationship of the Fiscal Condition-Predictability and District Student Performance with the study variables. The chapter will conclude with a summary.

\section{Survey Respondents}

251 of the 612 superintendents serving the public school districts across Ohio responded to study survey ( $41 \%$ return). 77 surveys had to be removed from the study because: (1) The survey was incomplete; or, (2) the survey was unidentifiable.

From the list of 174 completed and identifiable surveys, 111 were removed from participation in the primary study for not meeting the qualifications of the study. The 174 surveys are presented in the results as the inclusive list. The 63 responses which meet all the qualifications will be presented as the qualifying list. 
Of the 174 completed surveys received $148(85.1 \%)$ were from males and 26 $(14.9 \%)$ were from females. From the 63 surveys meeting all the qualifiers of the study, $55(87.3 \%)$ were male and $8(12.7 \%)$ were female. Statewide, serving public schools in Ohio $503(83 \%)$ were male and $102(17 \%)$ were female (see Table 6).

Table 6

Frequency Distribution of Participants by Gender

\begin{tabular}{llll}
\hline & & Male & Female \\
\hline Inclusive & $(\mathrm{N}=174)$ & $148(85.1 \%)$ & $26(14.9 \%)$ \\
Qualifiers & $(\mathrm{N}=63)$ & $55(87.3 \%)$ & $8(12.7 \%)$ \\
Statewide & $(\mathrm{N}=605)$ & $503(83 \%)$ & $102(17 \%)$ \\
\hline
\end{tabular}

Of the 174 superintendents responding 4 (2.3\%) were from urban districts; 62 (35.6\%) were from suburban; and $108(62.1 \%)$ were from rural ones. From the qualifying list 1 (1.6\%) was from an urban district; 19 (30.2\%) were from suburban; and $43(68.2 \%)$ were from rural ones. Statewide superintendents in Ohio public schools 20 (3.2\%) were from urban districts; 202 (33\%) were from suburban; and 390 (63.7\%) were from rural ones (see Table 7).

Table 7

Frequency Distribution of Participants by District Locale

\begin{tabular}{lllll}
\hline & & Urban & Suburban & Rural \\
\hline Inclusive & $(\mathrm{N}=174)$ & $4(2.3 \%)$ & $62(35.6 \%)$ & $108(62.1 \%)$ \\
Qualifiers & $(\mathrm{N}=63)$ & $1(1.6 \%)$ & $19(30.2 \%)$ & $43(68.2 \%)$ \\
Statewide & $(\mathrm{N}=612)$ & $20(3.2 \%)$ & $202(33 \%)$ & $390(63.7 \%)$ \\
\hline
\end{tabular}




\section{Variable Descriptive Statistics}

Of the 174 participants making up the inclusive list the mean (M) and standard deviation (SD) of the variables of the study district student performance was 95.21 and 5.06; Fiscal Condition-Predictability $\quad \mathrm{M}=0.49, \mathrm{SD}=0.15$; Fiscal ConditionSustainability $\mathrm{M}=0.05, \mathrm{SD}=0.01$; District Socio-Economic Status $\mathrm{M}=0.35, \mathrm{SD}=$ 0.19; School District Size $\mathrm{M}=2317.10, \mathrm{SD}=2183.81$; and District Expenditure per Pupil M=8824.32, $\mathrm{SD}=1377.42$ (see Table 8).

Table 8

Means and Standard Deviations of Study Variables: Inclusive

\begin{tabular}{lcc}
\hline & Mean & Std. Deviation \\
\hline Inclusive (N=174) & & \\
District Student Performance & 95.21 & 5.06 \\
Fiscal Condition-Predictability & 0.49 & 0.15 \\
Fiscal Condition-Sustainability & 0.05 & 0.01 \\
School District Size & 2371.10 & 2183.81 \\
District Socio-Economic Status & 0.35 & 0.19 \\
District Expenditure per Pupil & 8824.32 & 1377.42 \\
\hline
\end{tabular}

Of the 63 qualifying participants the mean (M) and standard deviation (SD) of the variables of the study district student performance was 95.51 and 5.13; Fiscal ConditionPredictability $\quad \mathrm{M}=0.51, \mathrm{SD}=0.14$; Fiscal Condition-Sustainability $\mathrm{M}=0.05, \mathrm{SD}=$ 0.01; District Socio-Economic Status $\mathrm{M}=0.37, \mathrm{SD}=0.21$; School District Size $\mathrm{M}=$ 2732.18, $\mathrm{SD}=2039.98$; and District Expenditure per Pupil $\mathrm{M}=8821.25, \mathrm{SD}=1414.47$ (see Table 9). 
Table 9

Means and Standard Deviations of Study Variable: Qualifying

\begin{tabular}{lcc}
\hline & Mean & Std. Deviation \\
\hline Qualifying (N=63) & & \\
District Student Performance & 95.51 & 5.13 \\
Fiscal Condition Predictability & 0.51 & 0.14 \\
Fiscal Condition Sustainability & 0.05 & 0.01 \\
School District Size & 2732.18 & 2039.98 \\
District Socio-Economic Status & 0.37 & 0.21 \\
District Expenditure per Pupil & 8821.25 & 1417.4 \\
\hline
\end{tabular}

Of the 612 school districts in Ohio the mean (M) and standard deviation (SD) of the variables of the study district student performance was 95.63 and 6.03; Fiscal Condition-Predictability

$\mathrm{M}=0.48, \mathrm{SD}=0.15 ;$ Fiscal Condition-Sustainability $\mathrm{M}=0.05, \mathrm{SD}=0.02$; District Socio-Economic Status $M=0.36, \mathrm{SD}=0.20$; School District Size $\mathrm{M}=2742.56, \mathrm{SD}=$ 4148.67; and District Expenditure per Pupil $\mathrm{M}=9073.47, \mathrm{SD}=2364.23$ (see Table 10) Table 10

Means and Standard Deviations of Study Variables: Statewide Mean Std. Deviation

Statewide $(\mathrm{N}=612)$

District Student Performance $95.63 \quad 6.03$

Fiscal Condition-Predictability 0.48

0.15

Fiscal Condition-Sustainability

0.05

0.02

School District Size

2742.56

4148.67 
Table 10 (continued)

\begin{tabular}{lcc}
\hline & Mean & Std. Deviation \\
\hline District Socio-Economic Status & 0.36 & 0.20 \\
District Expenditure per Pupil & 9073.47 & 2364.23 \\
\hline
\end{tabular}

\section{Correlation Matrices}

The Correlation Matrices of the study variables for the inclusive, qualifying and statewide lists did reveal significant relationships. It must be noted that none of these relationships were more than weak ones (Pearson values $<0.7 ;-0.7$ ).

The Correlation Matrices for our inclusive list revealed several significant relationships between our study variables. None of these relationships was reported to be anything but weak (Pearson Values $<0.7$ or -0.7 ). The greatest significant Pearson value reported was 0.432 between District Student Performance and District Fiscal ConditionsPredictability (see Table 11).

Table 11

Pearson Correlations for Study Variables: Inclusive

\begin{tabular}{|c|c|c|c|c|c|c|c|}
\hline & Variable & 2 & 3 & 4 & 5 & 6 & 7 \\
\hline \multicolumn{8}{|c|}{ Inclusive: $\mathrm{N}=174$} \\
\hline \multirow[t]{2}{*}{1} & District Student Performance & $-.432 * *$ & $-.294 *$ & k*.119 & $-2.13^{*}$ & *.044 & -.004 \\
\hline & & .000 & .000 & .118 & .002 & .561 & .962 \\
\hline \multirow[t]{2}{*}{2} & District Fiscal Condition-Predictability & & $.253 *$ & $*-.335 *$ & $\leqslant * .106$ & $-.425 * *$ & -.123 \\
\hline & & & .001 & .000 & .163 & .000 & .105 \\
\hline \multirow[t]{2}{*}{3} & District Fiscal Condition-Sustainability & & & -.106 & $.158 *$ & $.204 * *$ & -.079 \\
\hline & & & & .164 & .037 & .007 & .299 \\
\hline \multirow[t]{2}{*}{4} & School District Size & & & & .064 & $.185 *$ & .101 \\
\hline & & & & & .402 & .015 & .184 \\
\hline
\end{tabular}


Table 11 (continued)

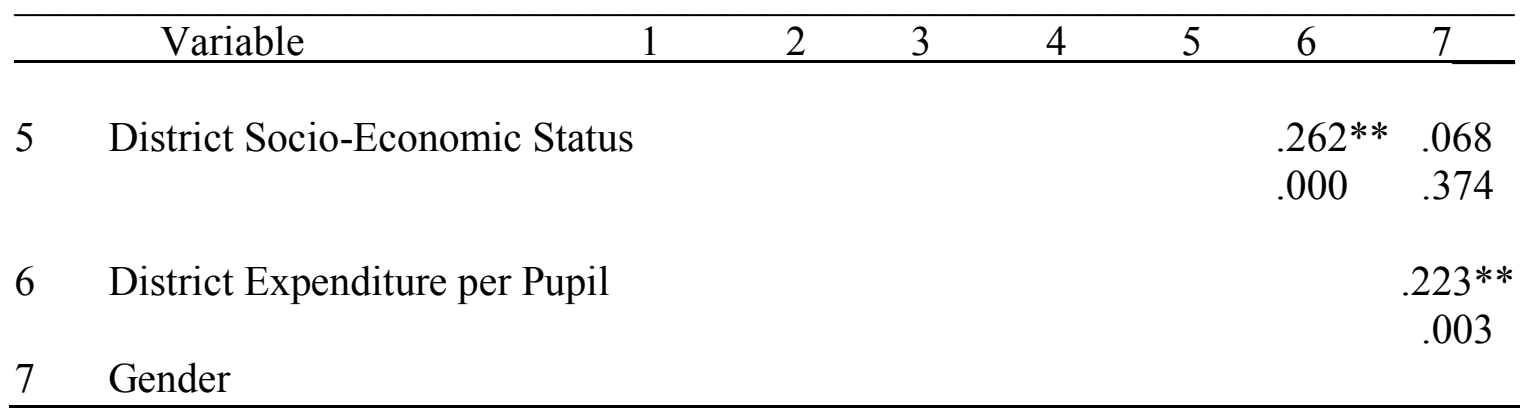

**Correlation is significant at the 0.01 level (2-tailed).

* Correlation is significant at the 0.05 level (2-tailed).

a. Listwise $\mathrm{N}=17$

The Correlation Matrices of the qualifying list did reveal significant relationships between study variables. None of the relationships revealed were strong (Pearson Values $>0.7$ or -0.7 ). Only the relationship between District Fiscal Condition-Predictability and District Expenditure per pupil was over 0.5 (-0.517) (see Table 12).

Table 12

Pearson Correlations for Study Variables: Qualifying

\begin{tabular}{rlllllll}
\hline Variable & 1 & 2 & 3 & 4 & 5 & 6 & 7 \\
\hline Qualifying: $\mathrm{N}=63$ & & & & & &
\end{tabular}

1 District Student Performance $\begin{array}{ccccccc}-.426 * * & -.322 * & -.053 & -.139 & -.128 & -.028 \\ & .000 & .010 & .680 & .276 & .316 & .828\end{array}$

2 District Fiscal Condition-Predictability $\quad .205-.425 * *-.174-.517 * *-.174$ $\begin{array}{lllll}.107 & .001 & .174 & .000 & .172\end{array}$

3 District Fiscal Condition-Sustainability $\quad \begin{array}{llll}0 & .057 & .216 & .321 * * .068\end{array}$ $\begin{array}{llll}.656 & .088 & .010 & .598\end{array}$

$4 \quad$ School District Size

$.304 * .456 * .205$

$.015 \quad .000 \quad .107$

5 District Socio-Economic Status 
Table 12 (continued)

\begin{tabular}{|c|c|c|c|c|c|c|c|c|}
\hline & Variable & 1 & 2 & 3 & 4 & 5 & 6 & 7 \\
\hline 6 & District Expenditure per Pupil & & & & & & & $\begin{array}{l}.186 \\
.140\end{array}$ \\
\hline 7 & Gender & & & & & & & \\
\hline
\end{tabular}

** Correlation is significant at the 0.01 level (2-tailed).

* Correlation is significant at the 0.05 level (2-tailed).

a. Listwise $\mathrm{N}=63$

The Correlation Matrices statewide for the study variables reported several significant relationships, none of which the relationships were found to be more than weak ones (Pearson Value $<0.7$ or -0.7 ). The greatest Pearson Value reported was 0.418 between District Fiscal Condition-Predictability and District Expenditure per Pupil (see Table 13).

Table 13

Pearson Correlations for Study Variables: Statewide

\begin{tabular}{cllllll}
\hline Variable & 1 & 2 & 3 & 4 & 5 & 6 \\
\hline Statewide: $\mathrm{N}=611$ & & & & &
\end{tabular}

Statewide: $\mathrm{N}=611$

1 District Student Performance $\quad \begin{array}{cccccc}-.364 * * & -.212 * & -.192 * * & -.252 * & -.083 * \\ & .000 & .000 & .000 & .000 & .041\end{array}$

2 District Fiscal Condition-Predictability $\quad .120^{* *}-.173^{* *} \quad .046 \quad-.418^{* *}$

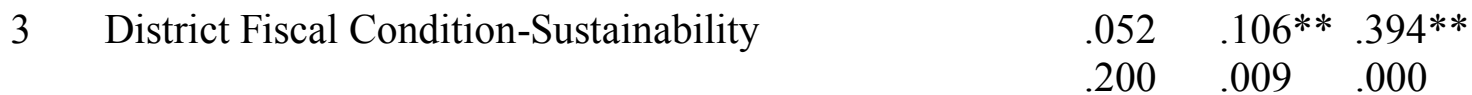

4 School District Size $\quad .240^{* *} .149^{* *}$

$.000 \quad .000$

5 District Socio-Economic Status $\quad .082^{*}$ 
Table 13 (continued)

\begin{tabular}{lccccccc}
\hline & Variable & 1 & 2 & 3 & 4 & 5 & 6 \\
\hline 6 & District Expenditure per Pupil & & & & & \\
\hline
\end{tabular}

** Correlation is significant at the 0.01 level (2-tailed).

* Correlation is significant at the 0.05 level (2-tailed).

\section{a. Listwise $\mathrm{N}=611$}

Multi-collinearity diagnostics were completed to investigate relationships of the study finance variables. Those included were district fiscal condition-sustainability, fiscal condition-predictability, district expenditure per pupil and district socio-economic status. The analysis revealed no issued with collinearity as the highest variance in factor (VIF) value reported was 1.630 .

\section{Regression Model}

A Linear Regression Model was utilized with three blocks successively entered to effectively evaluate the influence of the categorical variables school district locale and superintendent leadership style. Block one (1) was run with the criterion variables and predictor variables without either categorical variable. Step two involved adding a second block to the first.

The second block includes two categorical dummy variables identifying district locale: (1) rural and (2) urban. A third locale variable suburban was suppressed in order to enable it to function as the reference category. The suburban locale was differentiated because districts of this type are known to have higher expenditure per pupil, higher district student performance and a lower percentage of students qualifying for the federal free/reduced lunch program. 
Step three involved adding a third block to the first. The third block included three categorical dummy variables identifying superintendent leadership style: (1) singleframe; (2) paired-frame; and (3) multi-frame. A fourth leadership style variable no-frame was suppressed in order to enable it to function as the reference category. The non-frame leadership style was differentiated because the research of Bolman, Deal and others report leads to using three or more frames were more effective than those that use fewer. The fewer frame a leader works from within, the more limited the knowledge and skills sets are available.

\section{Research Questions}

Question 1: What are the leadership styles (as measured by the four frames) of superintendents across Ohio?

The inclusive list of superintendents across Ohio champion the multi-framed leadership style (37.4\%) the most followed by the single-frame $(24.7 \%)$, the paired frame $(23.6 \%)$ and the no-frame $(14.4 \%)$ the least.

Among the single, paired and multi-framed leadership styles the multi-framed structural-human resource-political-symbolic was reported the most $(20.1 \%)$ followed by the paired-frame structural-human resource $(14.9 \%)$ and then the single frame structural (12.1\%). These were the only ones reported to be utilized that were greater than $10 \%$ of total reported.

Qualifying superintendents across Ohio champion the multi-framed leadership style $(35.0 \%)$ the most followed by the single-frame $(27.0 \%)$ and then equally $(19 \%)$ the no-frame and paired-frame leadership styles. 
Among the single, paired and multi-framed leadership styles the multi-framed structural-human resource-political-symbolic was reported the most (15.9\%) followed by the single-frame structural $(14.3 \%)$ and the single-frame human resource and pairedframe structural-human resource both at $(11.1 \%)$. These were the only ones reported to be utilized that were greater than $10 \%$ of total reported (see Table 14).

Table 14

Frequency Distribution by Frame Pattern

\begin{tabular}{|c|c|c|c|c|c|c|}
\hline $\begin{array}{l}\text { Category/ } \\
\text { Pattern }\end{array}$ & $\begin{array}{l}\text { Qualifying } \\
\mathrm{N}\end{array}$ & $\begin{array}{l}\% \text { as to } \\
\text { Category }\end{array}$ & $\begin{array}{l}\% \text { as to } \\
\text { Total }\end{array}$ & $\begin{array}{l}\text { Inclu } \\
\text { to } \mathrm{N}\end{array}$ & $\begin{array}{l}\text { ive } \% \text { as } \\
\text { Category }\end{array}$ & $\begin{array}{l}\% \text { as to } \\
\text { Total }\end{array}$ \\
\hline No Frame & 12 & 100 & 19 & 25 & 100.0 & 14.4 \\
\hline \multicolumn{7}{|l|}{ Single-Frame } \\
\hline Structural & 9 & 52.9 & 14.3 & 21 & 49.0 & 12.1 \\
\hline \multicolumn{7}{|l|}{ Human } \\
\hline Resource & 7 & 41.2 & 11.1 & 17 & 40.0 & 9.8 \\
\hline Political & - & 0.0 & 0.0 & - & & \\
\hline Symbolic & 1 & 5.9 & 1.6 & 5 & 11.0 & 2.9 \\
\hline Sub Total & 17 & & 27 & 43 & & 24.7 \\
\hline \multicolumn{7}{|l|}{ Paired-Frame } \\
\hline \multicolumn{7}{|c|}{ Structural/Human } \\
\hline Resource & 7 & 58.3 & 11.1 & 26 & 63.5 & 14.9 \\
\hline \multicolumn{7}{|l|}{ Structural/ } \\
\hline Political & 2 & 16.6 & 3.2 & 2 & 4.9 & 1.2 \\
\hline $\begin{array}{l}\text { Structural/ } \\
\text { Symbolic }\end{array}$ & - & 0.0 & 0.0 & 0 & 0.0 & 0.0 \\
\hline $\begin{array}{l}\text { Human Resol } \\
\text { Political }\end{array}$ & ce/ & 0.0 & 0.0 & 4 & 9.7 & 2.3 \\
\hline
\end{tabular}


Table 14 (continued)

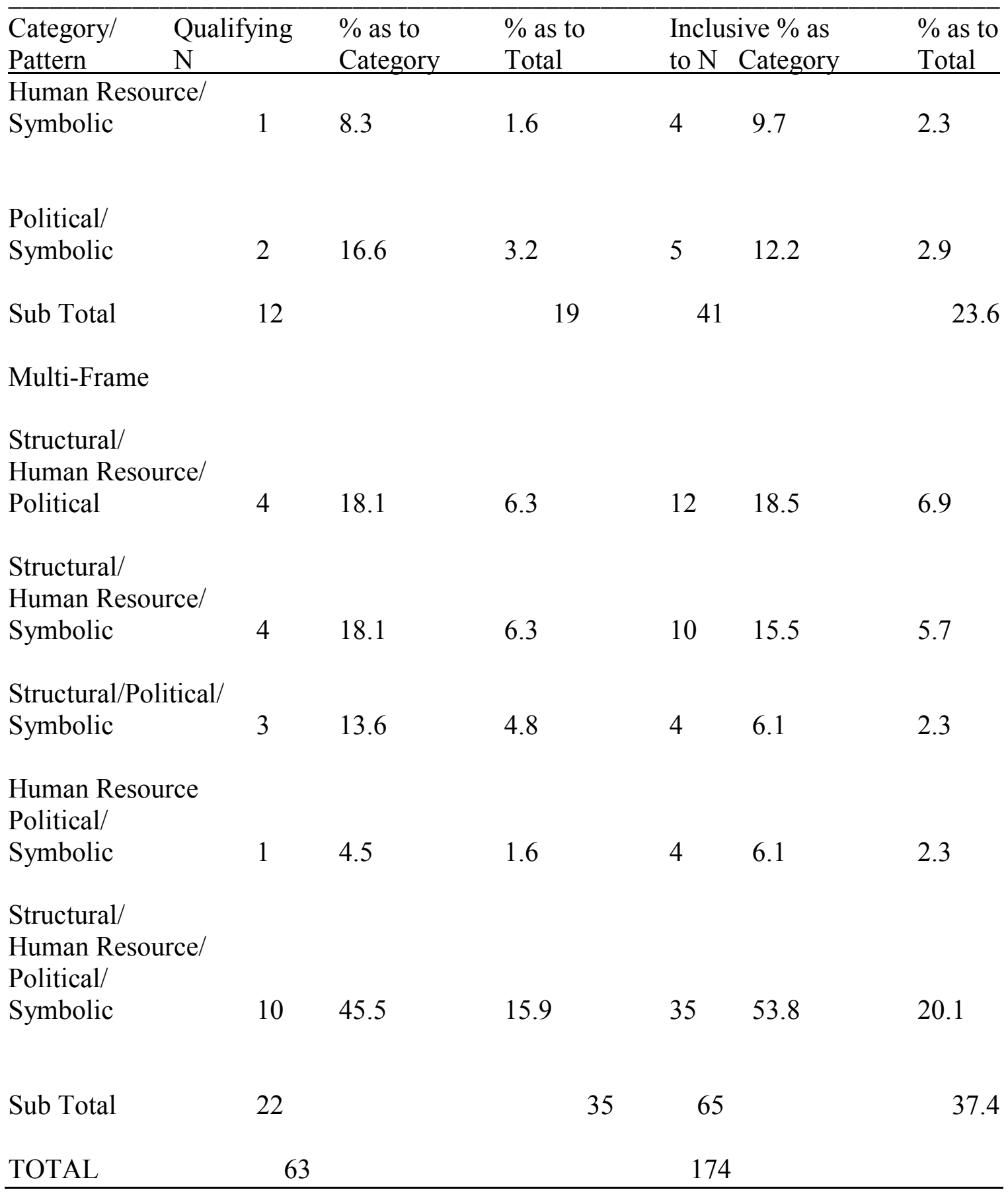

The inclusive list reveals the superintendents utilize the human-resource- frame $(29.5 \%)$ the most; followed by the structural-frame $(28.9 \%)$; then the symbolic $(17.6 \%)$; the political-frame (17.4\%); and the no-frame (6.6\%) the least (see Table 15$)$. 
Table 15

Utilization of Frame through Reported Frequency Pattern: Inclusive

\begin{tabular}{lll}
\hline Frame & $\mathrm{N}$ & $\%$ \\
No Frame & 25 & 6.6 \\
Structural & 110 & 28.9 \\
Human Resource & 112 & 29.5 \\
Political & 66 & 17.4 \\
Symbolic & 67 & 17.6 \\
\hline
\end{tabular}

Qualifying superintendents utilize the structural-frame (30.2\%) the most, followed by the human-resource- frame (26.3\%); the symbolic and political-frame $(17.1 \%)$ and the no-frame $(9.3 \%)$ the least (see Table 16$)$

Table 16

Utilization of Frame through Reported Frequency Pattern: Qualifying

\begin{tabular}{lll}
\hline Frame & $\mathrm{N}$ & $\%$ \\
No Frame & 12 & 9.3 \\
Structural & 39 & 30.2 \\
Human Resource & 34 & 26.3 \\
Political & 22 & 17.1 \\
Symbolic & 22 & 17.1 \\
\hline
\end{tabular}

Males and female superintendents, both qualifying and inclusive, report championing the multi-framed leadership style the most. Among males the single-frame styles is second followed by the paired and the no-frame style. Among females the usage beyond the multi-framed style varies between the qualifying and inclusive lists (see Table 17). 
Table 17

Frequency Distribution of Leadership Style by Gender

\begin{tabular}{lllll}
\hline Gender & None & Single & Paired & Multi \\
Inclusive $\mathrm{N}=174$ & & & \\
Male $\mathrm{N}=147(84.4 \%)$ & $25(14.4 \%)$ & $40(22.9 \%)$ & $33(19 \%)$ & $50(28.7 \%)$ \\
Female $\mathrm{N}=27(15.6 \%)$ & $2(1.1 \%)$ & $5(2.9 \%)$ & $6(3.5 \%)$ & $13(7.5 \%)$ \\
Qualifying $\mathrm{N}=63$ & & & \\
Male $\mathrm{N}=51(81 \%)$ & & & & \\
Female $\mathrm{N}=12(19 \%)$ & $1(1.5 \%)$ & $2(3.2 \%)$ & $0(0.0 \%)$ & $5(7.9 \%)$ \\
\hline
\end{tabular}

Question \#2: In consideration of appropriate control variables what are the individual and combined relationships of superintendent's gender, district size, district socioeconomic status, locale, per pupil expenditure, district fiscal condition-sustainability and district fiscal condition-predictability with superintendent leadership styles.

The study of the relationships with the superintendent leadership styles among the inclusive list were found not to be significant. The Linear Regression Models reported $\mathrm{p}$ value scores of 0.762 to 0.087 (see Table 18)

Table 18

Summary of Regression Analysis for Variables Influencing Superintendent Leadership Style: Inclusive

\begin{tabular}{llll}
\hline Variable & $\mathrm{B}$ & SEB & $B$ \\
\hline Inclusive: $\mathrm{N}=174$ & & & \\
School District Size & $6.93 \mathrm{E}-005$ & .000 & .139 \\
District Socio-Economic Status & .679 & .475 & .117
\end{tabular}


Table 18 (continued)

\begin{tabular}{llcc}
\hline Variable & B & SEB & $\beta$ \\
\hline District Expenditure per Pupil & $-2.61 \mathrm{E}-005$ & .000 & -.033 \\
Gender & .277 & .238 & .091 \\
Fiscal Condition-Predictability & -.230 & .756 & -.031 \\
Fiscal Condition-Sustainability & -2.209 & 7.591 & -.025 \\
\hline
\end{tabular}

Note: $R^{2}=0.056$

* $\quad \mathrm{P}<0.05$

** $\mathrm{P}<0.01$

$* * * \mathrm{P}<0.001$

The study of the relationships with the superintendent leadership styles were found not to be significant among the qualifying list. The Linear Regression Models reported $\mathrm{p}$ value scores of 0.990 to 0.197 (see Table 19).

Table 19

Summary of Regression Analysis for Variables Influencing Superintendent Leadership Style: Qualifying

\begin{tabular}{lccc}
\hline Variable & B & SEB & $\beta$ \\
Qualifying: N=63 & & & \\
School District Size & .000 & .000 & .263 \\
District Socio-Economic Status & .404 & .841 & .073 \\
District Expenditure per Pupil & .000 & .000 & -.281 \\
Gender & .315 & .462 & .092 \\
Fiscal Condition-Predictability & -.787 & 1.719 & -.095
\end{tabular}


Table 19 (continued)

\begin{tabular}{lccl}
\hline Variable & B & SEB & $\beta$ \\
\hline Fiscal Condition-Sustainability & 8.113 & 17.416 & .071 \\
\hline
\end{tabular}

Note: $R^{2}=0.100$

$* \quad \mathrm{P}<0.05$

** $\mathrm{P}<0.01$

$* * * \mathrm{P}<0.001$

Question 3: In consideration of appropriate control variables, what are the individual and combined relationships of superintendent's gender, district size, district socio-economic status, locale, per pupil expenditure, leadership style and fiscal condition-predictability with the fiscal condition-sustainability?

The relationships between district expenditure per pupil and district fiscal condition-predictability were the only variables found to be significant with district fiscal condition-sustainability in the inclusive group. Both variables have positive relationships with reported standardized beta scores.

As a school district's fiscal condition-sustainability increases the greater its dependency on state aid will be and the greater its expenditure per pupil will become (see Table 20).

Table 20

Summary of Regression Analysis for Variables Influencing Fiscal ConditionSustainability: Inclusive

\begin{tabular}{lccc}
\hline Variable & $\mathrm{B}$ & $\mathrm{SE} \mathrm{B}$ & \multicolumn{1}{c}{ B } \\
\hline Inclusive: $\mathrm{N}=174$ & & & \\
District Fiscal Condition-Predictability & .031 & .007 & $.378^{* * *}$ \\
School District Size & $1.17 \mathrm{E}-007$ & .000 & -.021
\end{tabular}


Table 20 (continued)

\begin{tabular}{llll}
\hline Variable & B & SE B & B \\
\hline District Socio-Economic Status & .002 & .005 & .023 \\
District Expenditure per Pupil & $3.62 \mathrm{E}-006$ & .000 & $.406^{* * * *}$ \\
Gender & -.004 & .002 & -.120 \\
Rural & .002 & .002 & .064 \\
\hline
\end{tabular}

Note: $R^{2}=0.201$

$* \quad \mathrm{P}<0.05$

** $\mathrm{P}<0.01$

$* * * \mathrm{P}<0.001$

The regression models indicate that up to $20.1 \%$ of the variability in the fiscal condition-sustainability is accounted for in the variables utilized in the models (see Table 20.1).

Table 20.1

Summary of $R^{2}$ values for Regression Models through Block Method: Inclusive

\begin{tabular}{clc}
\hline Block & Variable Introduced & $R^{2}$ \\
1 & & 0.198 \\
2 & Urban & 0.198 \\
& Rural & 0.201 \\
3 & Single & 0.199 \\
& Paired & 0.198 \\
& Multiple & 0.198 \\
\hline
\end{tabular}

The relationships between district expenditure per pupil and district fiscal condition-predictability were the only variables found to be significant with district fiscal 
condition-sustainability in the qualifying group. Both variables have positive relationships with reported standardized beta scores.

As a school district's sustainability increases the greater its dependency on state aid will become (fiscal condition-predictability) and the greater its expenditure per pupil will become (see Table 21).

Table 21

Summary of Regression Analysis for Variables Influencing Fiscal ConditionSustainability: Qualifying

\begin{tabular}{lccc}
\hline Variable & $\mathrm{B}$ & $\mathrm{SE}$ B & \multicolumn{1}{c}{ B } \\
\hline Qualifying: N=63 & & & $.579^{* * *}$ \\
District Fiscal Condition-Predictability & .042 & .010 & .140 \\
School District Size & $6.97 \mathrm{E}-077$ & .000 & .034 \\
District Socio-Economic Status & .002 & .006 & $.567^{* * *}$ \\
District Expenditure per Pupil & $4.02 \mathrm{E}-006$ & .000 & .016 \\
Gender & .000 & .004 & -.210 \\
Urban & -.017 & .011 &
\end{tabular}

Note: $R^{2}=0.320$

* $\quad \mathrm{P}<0.05$

** $\mathrm{P}<0.01$

$* * * \mathrm{P}<0.001$

The regression models indicate that up to $32.0 \%$ of the variability in the fiscal condition-sustainability is accounted for in the variables utilized in the models (see Table 21.1). 
Table 21.1

Summary of $R^{2}$ values for Regression Models through Block Method: Qualifying

\begin{tabular}{cll}
\hline Block & Variable Introduced & $R^{2}$ \\
\hline 1 & & 0.293 \\
2 & Urban & 0.320 \\
& Rural & 0.309 \\
3 & Single & 0.295 \\
& Paired & 0.293 \\
& Multiple & 0.293 \\
\hline
\end{tabular}

Question 4: In consideration of appropriate control variables, what are the individual and combined relationships of superintendent's gender, locale, per pupil expenditure and fiscal condition-stability with the district fiscal condition-predictability?

The relationships between school district size, district expenditure per pupil, fiscal condition-sustainability, district expenditure per pupil and rural were found to be significant with the fiscal condition-predictability in the inclusive group. Relationships with fiscal condition-sustainability, district socio-economic status and rural were found to be positive through the beta standardized scores while those with district expenditure per pupil and school district size were found to be negative.

As a school district's dependence on state basic aid increases (predictability) the smaller the school district size, the lower the district per pupil expenditure will be and the more sustainable its fiscal condition becomes, the greater percentage of student qualifying for the federal free/reduced lunch program will be and the more likely the locale of the district is to be rural versus suburban (see Table 22). 


\section{Table 22}

Summary of Regression Analysis for Variables Influencing Fiscal ConditionPredictability: Inclusive

\begin{tabular}{lccc}
\hline Variable & B & SE B & B \\
\hline Inclusive: $\mathrm{N}=174$ & & & $.281^{* * *}$ \\
District Fiscal Condition-Sustainability & 3.375 & .757 & $-.178^{* *}$ \\
School District Size & $-1.20 \mathrm{E}-005$ & .000 & $.199^{* *}$ \\
District Socio-Economic Status & .156 & .049 & $-.465^{* * *}$ \\
District Expenditure per Pupil & $-4.97 \mathrm{E}-005$ & .000 & .014 \\
Gender & .006 & .026 & $.157^{* *}$ \\
\hline
\end{tabular}

Note: $R^{2}=0.405$

$* \quad \mathrm{P}<0.05$

$* * \mathrm{P}<0.01$

$* * * \mathrm{P}<0.001$

The regression models indicate that up to $40.5 \%$ of the variability in the fiscal condition predictability can be accounted for in the variables in the models (see Table 22.1).

Table 22.1

Summary of $R^{2}$ values for Regression Models through Block Method: Inclusive

\begin{tabular}{clc}
\hline Block & Variable Introduced & $R^{2}$ \\
\hline 1 & & 0.385 \\
2 & Urban & 0.391 \\
& Rural & 0.405 \\
3 & Single & 0.385 \\
& Paired & 0.385
\end{tabular}


Table 22.1 (continued)

\begin{tabular}{llc}
\hline Block & Variable Introduced & $R^{2}$ \\
& Multiple & 0.385 \\
\hline
\end{tabular}

The relationships between school district size, district expenditure per pupil, and fiscal condition-sustainability and urban locale were found to be significant with district fiscal condition-predictability among the qualifying group. Fiscal conditionsustainability and rural locale were found to have positive relationships through the beta standardized score while district expenditure per pupil and school district size were found to have negative relationships.

As a school district's dependence on state basic aid increases (predictability) the smaller the school district size, the lower the district per pupil expenditure will be and the more sustainable its fiscal condition becomes. The district will tend to be urban locale versus suburban (see Table 23).

Table 23

Summary of Regression Analysis for Variables Influencing Fiscal ConditionPredictability: Qualifying

\begin{tabular}{lccc}
\hline Variable & $\mathrm{B}$ & $\mathrm{SE} \mathrm{B}$ & $\mathrm{B}$ \\
\hline Qualifying: N=63 & & & \\
District Fiscal Condition-Sustainability & 5.442 & 1.340 & $.393^{* * *}$ \\
School District Size & $-2.65 \mathrm{E} 005$ & .000 & $-.388^{* *}$ \\
District Socio-Economic Status & .042 & .072 & .063 \\
District Expenditure per Pupil & $-5.32 \mathrm{E}-005$ & .000 & $-.542^{* * *}$ \\
Gender & -.009 & .040 & -.021
\end{tabular}


Table 23 (continued)

\begin{tabular}{llll}
\hline Variable & B & SE B & $\beta$ \\
\hline Urban & .368 & .122 & $.333^{* *}$ \\
\hline
\end{tabular}

Note: $R^{2}=0.539$

* $\mathrm{P}<0.05$

** $\mathrm{P}<0.01$

$* * * \mathrm{P}<0.001$

The regression models indicate that up to $53.9 \%$ of the variability in the fiscal condition predictability can be accounted for in the variables in the models (see Table 23.1)

Table 23.1

Summary of $R^{2}$ values for Regression Models through Block Method: Qualifying

\begin{tabular}{clc}
\hline Block & Variable Introduced & $R^{2}$ \\
\hline 1 & & 0.463 \\
2 & Urban & 0.539 \\
& Rural & 0.466 \\
3 & Single & 0.464 \\
& Paired & 0.467 \\
& Multiple & 0.464 \\
\hline
\end{tabular}

Question 5: In consideration of appropriate control variables, what are the individual and combined relationships of superintendent's gender, district, fiscal conditionsustainability, fiscal condition predictability, locale, and superintendent's leadership style on district student performance? 
The relationships between district fiscal condition-predictability and district fiscal condition-sustainability with district student performance were found to be significant among the inclusive group. Both variables had negative relationships as indicated through the standardized beta scores.

As a school district's student performance increases the school district's dependency on state basic aid (predictability) and the fiscal condition-sustainability decreases (see Table 24).

Table 24

Summary of Regression Analysis for Variables Influencing District Student Performance: Inclusive

\begin{tabular}{lrcc}
\hline Variable & B & SE B & \multicolumn{1}{c}{ B } \\
Inclusive: N=174 & & & \\
School District Size & $2.67 \mathrm{E}-005$ & .000 & .012 \\
District Socio-Economic Status & -3.648 & 1.933 & -.135 \\
District Expenditure per Pupil & -.000 & .000 & -.033 \\
Gender & -.625 & .976 & -.044 \\
Fiscal Condition-Predictability & -13.335 & 2.928 & $-.388^{* * *}$ \\
Fiscal Condition-Sustainability & -68.425 & 30.625 & $-.166^{*}$ \\
Urban & -3.970 & 2.310 & -.118 \\
\hline
\end{tabular}

Note: $R^{2}=0.266$

* $\quad \mathrm{P}<0.05$

** $\mathrm{P}<0.01$

$* * * \mathrm{P}<0.001$

The regression models indicate up to $26.6 \%$ of the variability in district student performance can be accounted for by the study variables (see Table 24.1). 
Table 24.1

Summary of $R^{2}$-values for Regression Models through Block Method: Inclusive

\begin{tabular}{clc}
\hline Block & Variable Introduced & $R^{2}$ \\
\hline 1 & & 0.253 \\
2 & Urban & 0.266 \\
& Rural & 0.257 \\
3 & Single & 0.258 \\
& Paired & 0.254 \\
& Multiple & 0.256 \\
\hline
\end{tabular}

The relationships between district expenditure per pupil and fiscal conditionpredictability were found to be significant with district student performance among the qualifying group. Both variables had negative relationships as indicated through the standardized beta scores. The model indicates as student district performance increases district expenditure per pupil and the district's fiscal condition-predictability decreases.

As a school district's student performance increases its expenditure per pupil and its dependency on state basic aid (predictability) decrease (see Table 25).

Table 25

Summary of Regression Analysis for Variables Influencing District Student Performance: Qualifying

\begin{tabular}{lrrc}
\hline Variable & B & SE B & \multicolumn{1}{c}{ B } \\
Qualifying: N=63 & & & \\
School District Size & $3.67 \mathrm{E}-005$ & .000 & .015 \\
District Socio-Economic Status & .797 & 3.048 & .032 \\
District Expenditure per Pupil & -.001 & .001 & $-.374^{*}$
\end{tabular}


Table 25 (continued)

\begin{tabular}{lccc}
\hline Variable & B & SE B & \multicolumn{1}{c}{ B } \\
\hline Gender & -1.208 & 1.687 & -.079 \\
Fiscal Condition-Predictability & -21.615 & 5.610 & $-.587 * * *$ \\
Fiscal Condition-Sustainability & -44.08 & 64.010 & -.087 \\
Urban & -10.696 & 5.504 & -.263 \\
\hline
\end{tabular}

Note: $R^{2}=0.441$

* $\quad \mathrm{P}<0.05$

** $\mathrm{P}<0.01$

$* * * \mathrm{P}<0.001$

The regression models indicate up to $44.1 \%$ of the variability in district student performance can be accounted for in the variables in the models (see Table 25.1).

Table 25.1

Summary of $R^{2}$ values for Regression Models through Block Method: Qualifying

\begin{tabular}{clc}
\hline Block & Variable Introduced & $R^{2}$ \\
\hline 1 & & 0.371 \\
2 & Urban & 0.441 \\
& Rural & 0.374 \\
& Single & 0.372 \\
& Paired & 0.292 \\
& Multiple & 0.295 \\
\hline
\end{tabular}




\section{Ancillary Analysis}

In an attempt to more deeply investigate the relationship of the criterion variables: Fiscal conditions - sustainability, district school size, district student performance, district expenditure per pupil and district socio-economic status with district fiscal condition predictability and district student performance, an ancillary analysis was completed utilizing data reported on the 611 school districts across Ohio.

As was reported in the primary study of the relationships of the predictor variables with fiscal condition-predictability with the exception of the significance of rural locale, school district size, district student performance, district expenditure per pupil, and district student performance were significant. The relationships with school district size, district student performance and district expenditure per pupil were negative ones while those with fiscal condition-sustainability and rural locale were positive.

As a school district dependence on state basic aid (predictability) increases the size of the district, the district expenditure per pupil and the district student performance becomes less while the fiscal condition-sustainability increases. Those districts are more likely to be rural than suburban (see Table 26).

Table 26

Summary of Regression Analysis for Variables Influencing District Fiscal Condition Predictability: Statewide

\begin{tabular}{lrcc}
\hline Variable & B & SE B & \multicolumn{1}{c}{$\beta$} \\
\hline Statewide: N=611 & & & \\
School District Size & -4.14 E-006 & .000 & $-.113^{* *}$ \\
District Socio-Economic Status & .037 & .025 & .048 \\
District Expenditure per Pupil & $-2.57 \mathrm{E}-005$ & .000 & $-.402^{* * *}$
\end{tabular}


Table 26 (continued)

\begin{tabular}{llll}
\hline Variable & B & SE B & $\beta$ \\
\hline Fiscal Condition Sustainability & .811 & .227 & $.114^{* * *}$ \\
Rural & .081 & .011 & $.257^{* * *}$ \\
\hline
\end{tabular}

Note: $R^{2}=0.441$

* $\quad \mathrm{P}<0.05$

$* * \mathrm{P}<0.01$

$* * * \mathrm{P}<0.001$

The regression models utilized reported from $44.1 \%$ to $38.7 \%$ of the variability in fiscal condition predictability was the result of the predictor variables utilized (see Table 26.1).

Table 26.1

Summary of $R^{2}$ values for Regression Models through Block Method: Statewide

\begin{tabular}{ccc}
\hline Block & Variable Introduced & $R^{2}$ \\
\hline 1 & & 0.387 \\
2 & Urban & 0.387 \\
& Rural & 0.441 \\
\hline
\end{tabular}

As discovered in the primary study of the relationship of the criterion variables with district student performance with the exception of the significance of urban locale, district student performance, school district size, district socio-economic status, district expenditure per pupil, fiscal condition-predictability and fiscal condition-sustainability were found to be significant. All of the relationships were found to be negative ones. As district student performance increases the school district size, the percentage of students qualifying for the federal free/reduced lunch program, the district expenditure 
per pupil decreases, the school districts dependency on state basic aid (predictability) and the district fiscal condition-sustainability decrease. The school district is more likely to be suburban than urban (see Table 27).

Table 27

Summary of Regression Analysis for Variables Influencing District Student Performance: Statewide

\begin{tabular}{lrcc}
\hline Variable & B & SE B & \multicolumn{1}{c}{ ( } \\
Statewide: N=611 & .000 & .000 & $-.087^{*}$ \\
School District Size & -4.142 & 1.060 & $-.136^{* * *}$ \\
District Socio-Economic Status & .000 & .000 & $-.193^{* * *}$ \\
District Expenditure per Pupil & -17.766 & 1.538 & $-.446^{* * *}$ \\
Fiscal Condition-Predictability & -26.831 & 9.993 & $-.095^{* * *}$ \\
Fiscal Condition-Sustainability & -7.837 & 1.341 & $-.231^{* * *}$ \\
\hline Urban & & &
\end{tabular}

Note: $R^{2}=0.326$

$* \quad \mathrm{P}<0.05$

** $\mathrm{P}<0.01$

$* * * \mathrm{P}<0.001$

The regression models utilized reported from $28.8 \%$ to $32.6 \%$ of the variability in fiscal condition predictability was the result of the predictor variables utilized (see Table 27a).

Table 27.1

Summary of $R^{2}$ values for Regression Models through Block Method: Statewide

\begin{tabular}{ccc}
\hline Block & Variable Introduced & $R^{2}$ \\
\hline 1 & & 0.288 \\
2 & Urban & 0.326 \\
& Rural & 0.288 \\
\hline
\end{tabular}




\section{Summary}

In summary, the inclusive list of superintendent's leadership styles (as measured by the Bolman \& Deal frames) utilize the multi-frame style most frequently, followed by the single-frame style, the paired-frame and no-frame style the least. Within these styles the human-resource frame was utilized the most followed by the structural frame, the symbolic frame, and lastly the political-frame.

It was discovered the relationships of superintendent's gender, district size, socioeconomic status, locale, per pupil expenditure, district fiscal condition-sustainability and district fiscal condition-predictability with superintendent leadership style were not significant.

The relationships of district expenditure per pupil and fiscal conditionpredictability were found to be significant with the district fiscal condition-sustainability. The models were found to account for up to $20.1 \%$ of the variability in the criterion variable.

The relationships of district fiscal condition-sustainability, school size, district expenditure per pupil, and district socio-economic status were found to be significant with the district's' fiscal condition-predictability and the district was found to be more likely rural than suburban. The models were found to account for up to $40.5 \%$ of the variability of our criterion variable.

The relationships of district fiscal condition-sustainability and the district fiscal condition-predictability were found to be significant with the district student performance. The models were able to account for up to $26.6 \%$ of the variability of our criterion variable. 
The qualifying superintendent's leadership styles (as measured by the Bolman \& Deal frames) utilize the multi-frame style most frequently followed by the single-frame style and equally the paired-frame and no-frame styles. Within these styles the structural frame was utilized the most, followed by the human-resource frame, the symbolic frame, and the political-frame utilized the least.

It was discovered the relationships of superintendent's gender, district size, socio-economic status, locale, per pupil expenditure, district fiscal conditionsustainability and district fiscal condition-predictability with superintendent leadership style were not significant.

The relationships of district expenditure per pupil and fiscal conditionpredictability were found to be significant with the district fiscal condition-sustainability. The models were found to account for up to $32.6 \%$ of the variability in the criterion variable.

The relationships of school size, district expenditure per pupil, and fiscal condition-sustainability were found to be significant with the district's' fiscal conditionpredictability. The models were found to account for up to $63.7 \%$ of the variability of our criterion variable.

The relationships of district per pupil expenditure and the district fiscal conditionpredictability were found to be significant with the district student performance. The models were able to account for up to $44.1 \%$ of the variability of our criterion variable.

An ancillary analysis was completed utilizing the data from 611 school districts across Ohio to more deeply investigate the relationships of the predictor variables, fiscal condition sustainability, district expenditure per pupil, district student performance, 
school district size, district socio-economic status with district fiscal conditionpredictability and district student performance. This was done because of the findings in the primary study that revealed the predictor variables were responsible for a high percentage of the variability in district fiscal condition - predictability (53.9\%) and district student performance (44.1\%). This ancillary analysis revealed that statewide up to $44.1 \%$ of the variability in district fiscal condition-predictability was accounted for by the predictor variables and up to $32.6 \%$ of the variability in district studies performance was accounted for by the predictor variables.

These results will be discussed in greater detail in Chapter 5 . 


\section{Chapter 5}

\section{Conclusions and Recommendations}

This chapter forms conclusions and recommendations on the findings relevant to the relationships of superintendent leadership styles, district fiscal conditionspredictability, district fiscal condition-sustainability and district student performance. This chapter is comprised of three major sections: A study summary; conclusions; and recommendations for practice and for future studies.

\section{Summary of Study}

This study examined the relationships of superintendent's leadership styles, district size, district socio-economic status, gender, locale, district expenditure per pupil district fiscal conditions-predictability, and district fiscal condition-sustainability with district student performance across Ohio. The study is a post hoc study spanning 5 biennial funding periods (1997-2007). The major focus is whether or not there exists significant relationships among the study variables: gender, locale, superintendent leadership style, district fiscal condition-predictability, district fiscal conditionsustainability, school district size, district socio-economic status and district expenditure per pupil with superintendent leadership styles, district student performance, district fiscal condition- predictability and district condition-sustainability. Leadership styles are based upon Bolman and Deals (1991-2003) cognitive frames - structural, human resource, political and symbolic - which define organizational behaviors and governance patterns. The district student performance, a performance index value calculated by the Ohio Department of Education, serves as an indicator of the performance of a district compared to districts statewide. School district fiscal condition-predictability is the 
annual average (\%) in state basic aid over the 5 biennial funding periods. School district fiscal condition-sustainability is the average increase (\%) in district per pupil expenditure for this same time period. The district socio-economic status represents the percentage of students within the district that qualifies for the Federal Free/Reduced Lunch Program. District size, locale and per pupil expenditure is based on information provided by the Ohio Department of Education.

\section{Conclusions}

The conclusions are based on an analysis of the research questions utilizing both the qualifying superintendents, the inclusive group of superintendents and an ancillary analysis of the 611 school districts across Ohio to more deeply investigate the relationship of the criterion variables: fiscal conditions - sustainability, district school size, district student performance, district expenditure per pupil and district socioeconomic status with district fiscal-condition predictability and district student performance.

\section{Patterns of Superintendent Leadership Styles}

Qualifying Superintendents. The frequency distribution of leadership styles reported superintendents using the multi-frame leadership style $(35.0 \%)$ the most often. This was followed by the single-frame leader (27.0\%) and equally the paired-frame leader and no-frame leader (11\%).

This does differ from other leadership studies where Stankus (2009) reported the noframe leader was prominent among principals and Chang (2004) reported the same among college department chairs. But, similar findings were reported by Bowen (2000) among county program coordinators and Small (2002) among nursing department chairs. 
Bolman's (2003) research reported that those leaders using three or more frames were more effective than those who use fewer. Ohio's' superintendents, Bolman would argue, are using the most effective leadership style.

The research revealed the single frame (27.0\%) leader was utilized the second most. This is similar to results reported in Griffins (2005) study of biology and English chairs (32.9\%) and Small (2002) study (20.8\%), but differs significantly from Mathis (1999) reporting (11\%), Chang (2004) reporting (14.8\%) and Mosser (2000) reporting (16.6\%) utilizing the single frame leadership style. It was found that superintendents espousing the single frame leadership style the structural frame was utilized the most. In fact, the structural frame was utilized most among the superintendents utilizing the paired-frame and multi-frame leadership styles. Bolman (1997) found structural framed leaders espoused organizational charts, rules and standard operating procedures and policies minimizing problems while increasing quality and performance. Chang (2004) also found the leaders operating from single-framed leadership style have a better technology infrastructure and were more likely to provide both administrative and technical support while attending to key issues. Interesting to note is that Bolman and Deal (1997) cautions that effectiveness as a manager can be associated with the structural frame, reporting that the primary determinates of a successful leader are the symbolic and political frames.

The paired-frame leadership style was championed by $19 \%$ of the qualifying superintendents. This differs somewhat the studies of Stankus (2009) who reported 9\% of principals of smaller communities espoused the paired-frame style and those reported by Chang (2004), 13.6\%; Griffin (2005), 25\%; and Small (2002), 10.9\%. 
Qualifying superintendents championing the paired-frame leadership style reported using the structural-human resource pair the most (58.3\%) within the subgroup and (11.1\%) of the whole. This was consistent with Griffins' (2005) study, but did vary from Stankus (2009) who found the paired-frame structural-political pair to be utilized the most. In a study by Mathis (1999), it was reported the human resource-political frame was utilized the most. An understanding of the leadership frames can make a leader become more effective.

The multi-frame leadership style was championed most by qualifying superintendents across Ohio (37.4\%). This is consistent with Stankus' (2009) finding $31 \%$, but was much higher than those reported by Chang (2004) $14.8 \%$ and Griffin (2005) 18.1\%. Mathis (1999) discovered a much higher frequency of the multi-frame style usage reporting a $48.2 \%$ rate. Bolman and Deal (2003) would argue these superintendents are practicing effective leadership.

Inclusive Superintendents. The frequency distribution of leadership styles reported superintendents using the multi-frame leadership style (37.4\%) the most often. This was followed by the single-frame leader (24.7\%) the paired-frame leader (23.6\%) and the no-frame leader (14\%). This was consistent with the results of the qualifying superintendents.

Among single frame leadership style the inclusive superintendents utilized the human-resource frame the most. As with the qualifying group the human resource and the structural-frames were espoused the most far outnumbering all others. Bolman (1997) reported leaders espousing the human-resource frame promote openness, 
participation, empowerment and view the members of the organization as the primary resource.

\section{Relationships with Superintendent Leadership Styles}

The study among the qualifying and inclusive groups of superintendents revealed none of the predictor variables to be significant with the leadership styles of superintendent.

This appears to be contrary to the research of Waters and Marzano (2002) who found superintendent's practices to have a positive effect on student achievement. While it must be noted their study investigated practices and not leadership styles. Research on effective schools has evolved through four generations of studies with current research practices focusing on the effect of central office and superintendent leadership. This study found no significant relationships with the study variables.

\section{Relationships with District Fiscal Condition-Sustainability}

Qualifying superintendents. The study found the relationship of the predictor variables district expenditure per pupil and the district fiscal condition-predictability to be significant with district fiscal condition-sustainability. It was determined that up to $32.0 \%$ of the variability of our criterion variable was accounted for by the predictor variables. Both relationships were positive ones as reflected in the beta standardized scores.

These finding reinforce the Ammar et al (2005) argument describing the relationship of these variables. They argue that poor fiscal conditions can be avoided through predictable and sustainable practices. 
Inclusive superintendents. The study found the relationship of the predictor variables district expenditure per pupil and the district fiscal condition-predictability to be significant with district fiscal condition-sustainability. It was determined that up to $20.1 \%$ of the variability of our criterion variable was accented far by the predictor variables. Both relationships were positive ones reflected through beta standardized scores.

These findings also reinforce the Ammar et al (2005) argument describing the relationship of these financial variables.

\section{Relationships with District Fiscal Conditions-Predictability}

Qualifying superintendents. The predictor variables district fiscal conditionssustainability; district expenditure per pupil and district school size were found to be significant with district fiscal condition-predictability. The relationships with district fiscal condition sustainability was a positive one, while those with district expenditure per pupil, and school district size were all negative ones through reported beta standardized scores. The study found $53.9 \%$ of the variability of the criterion variable is the result of the relationships of the predictor variables.

The positive relationship among fiscal conditions predictability and sustainability affirm the study of Ammar et al (2005) where they argue future poor fiscal condition can be avoided through good fiscal predictability and stability practices. Those districts that rely more heavily on state basic aid provide greater stability to the school district fiscal system. Ammar et al stressed the importance of predictability and stability of school funding, especially among low poverty, high state aid districts. 
The negative relationship of district fiscal condition-predictability with district expenditure per pupil, and district school size would indicate the more a district relies on aid from the state the less it spends per pupil and the smaller the school district size.

This study indicated the more a school district in Ohio depends on state basic aid the smaller the school district is likely to be. Much research has been completed on school size and student achievement and the results are varied. Baker (1986) concluding size by itself is not a sole determining factor of student achievement. Huang and Howley (1993) and Howley (1999) reported students from high socio-economic status were less likely to be affected by school size.

From this study it is apparent the more a school district depends on state basic aid, the more likely its funding mechanism will be more sustainable and the district will tend to become smaller and spend less per pupil.

Inclusive superintendents. Among the inclusive list not only were the relationships of district fiscal conditions-sustainability, district expenditure per pupil, and school district school size found to be significant with district fiscal conditionpredictability as reported in the qualifying list, but in addition, so was district socioeconomic status. It was also found, within the inclusive list, school districts would more likely be rural than suburban. The relationships with district fiscal conditionsustainability and district socio-economic status were positive ones as reported with beta standardized scores while those with district expenditure per pupil and school district size were negative. Analysis of the inclusive group of superintendents revealed up to $40.5 \%$ of the variability of the criterion variable is the result of the predictor variables. 
The study of the inclusive list reveals the more a school district depends on state basic aid its funding mechanism becomes more sustainable; however, the school district will tend to become smaller, spend less per pupil, have an increase of students qualifying for free/reduced price lunch programs and tend to be rural vs. suburban in locale.

\section{Relationships with Student Performance}

Qualifying superintendents. Analysis of the qualifying group of superintendents revealed the relationship district expenditure per pupil and fiscal conditions-predictability to be significant with our criterion variable district student performance. Both relationships were reported as negative through the beta standardized scores. Up to $44.1 \%$ of the variability in district student performance can be accounted for by our study variables.

As a district's student performance increases it spends less per pupil and depends less upon the State of Ohio for basic aid. Expenditure per pupil reported by the American Legislative Exchange Council (2000) found no correlation between increased funding and student achievement. Similar findings are evident in Odden (1994), Skandera and Sousa (2002), Green and Trivitt (2003). Overall, the last three decades has not led to increased student achievement, but not for a lack of spending. However, it must be noted in studies such as Odden (1994), Brorsen and Jacques (2000) and Odden and Piccus (2007) in school systems where the money has been spent on instructional research-based practices and resources that directly affect instruction student achievement does increase.

Inclusive Superintendents. Analysis of the inclusive group of superintendents found the relationships of fiscal condition-sustainability and fiscal conditionpredictability to be significant with our criterion variable district student performance. 
Both relationships were reported to be negative through standardized beta scores. Up to $26.6 \%$ of the variability in district student performance can be accounted for by our study variables.

As a district's student performance increases its fiscal condition-sustainability decreases slightly and its dependence on state basic aide becomes less.

From this study it is apparent the more a school district depends on state basic aid the lower the student achievement. This affirms the works of Cavenaugh (2007), Campbell and Silver (1999). Although these works were completed within low wealth rural school districts they found deficits occurred including lower test scores and increased dropout rates. These same results were discovered by Roscignio and Crowley (2001). Cavenaugh (2007) reported the U.S. system tends to provide underprivileged students with a less demanding curriculum and poorly qualified teachers resulting in lower student achievement. The National Office for Research Measurement and Evaluating Systems (NORMES) at the University of Arkansas found schools with a greater percentage of free and reduced lunch participants are more likely to have district student performance below the state average. State and federal education policies and funding should not be formulated purely on political expediency, but on empirical research and carefully considered objectives to assure measurable outcomes and equitable opportunities for all children (Sughrue, 1997).

\section{Ancillary Analysis}

In an attempt to more deeply investigate the relationships with the criterion variables district student performance and district fiscal conditions-predictability an 
ancillary analysis using data available from 611 public schools across Ohio was completed. These findings perhaps are the most important contribution of the study.

Relationships with district fiscal condition-predictability. The ancillary

analysis revealed the relationships of school district size, district expenditure per pupil, fiscal condition-sustainability and district locale were significant with our criterion variable fiscal condition-predictability. The relationships with school district size and district expenditure per pupil were negative reported through standardized beta scores, while those with district fiscal condition-sustainability and locale (rural) were positive. The analysis also revealed up to $44.1 \%$ of the variability in our criterion variable can be accounted for in the study variables.

As a school district dependency on the state for basic aid increases the school district size, district per pupil expenditure and the district student performance becomes less. The district fiscal condition-sustainability increases. The school district will also tend to be a rural locale versus suburban.

Relationships with district student performance. The ancillary analysis revealed the relationships of school district size, district socio-economic status, district expenditure per pupil, fiscal condition-predictability; fiscal condition-sustainability and locale are significant with district student performance. All of these relationships were negative as reflected in reported beta standardized scores.

When school districts are smaller, have fewer students qualifying for free/reduced lunch programs, spend less per pupil, depend less on the state of Ohio for basic aid and have a lower district fiscal condition sustainability, student performance increases. The district will also tend to be suburban versus urban. 
The district tendency to be suburban versus urban reinforces the work of Irshman (1997) that discussed how urban areas had high concentrations of disadvantaged students who were ill-served that resulted in poor student performance. Similar findings were reported by (Lee \& Smith 1987), who found students in high schools smaller than 600 and larger than 900 experienced lower student achievement in reading and mathematics. Overbag (2003) reported similar results.

\section{Study Implications}

There are several implications from the study. These implications reflect both the relationships of the leadership styles of the superintendents as well the relationships of the fiscal conditions of school districts across Ohio.

Opportunities must be provided to individuals in leadership roles and to those that aspire to theses positions to develop them to become multi-framed style individuals. It is apparent that multi-framed style leaders have greater knowledge and more varied skills sets to most effectively lead their organization. Bolman and Deal (2003) share several methods to help individuals utilize and strengthen specific frame usage. These techniques and others must be utilized to help strengthen and to teach frame utilization to individuals that lack usage of the individual frames in the effort to become a multiframed style leader.

The findings of the relationships of increased student performance with school districts that receive less state basic aid and with school districts that spend less on per pupil expenditures needs further investigation to provide a deeper understanding. Since districts that receive less state basic aid spend a greater amount of dollars per pupil it is apparent that the availability of resources does matter in increasing student performance 
across Ohio. The finding that student performance is higher in those districts that over the period of the study spent a smaller percentage per pupil expenditure would indicate that where the dollars are being spent does matter. Policy makers, our legislators and the leadership within the schools need to be provided these findings. Future studies must be completed that to unwrap these relationships to provide a deeper understanding

The finding of the existence of a state funding equalization plan in Ohio must be investigated further to monitor its level of effectiveness. The effectiveness of the school funding equalization plan that was utilized during the study period was very minimal. It would take a significantly long period of time for equalization of school funding to occur between districts of low fiscal capacity with those of high capacity to. More studies investigating these relationships are necessary to be able to provide a deeper understanding of Ohio's equalization plan to the policy makers and our legislators.

\section{Recommendations}

\section{Recommendations for Practice}

As effective schools research is entering the fourth generation of research it is evident more leadership studies of superintendents of schools is necessary. Research on leadership practices and styles is important if we are to understand why some school districts are successful while others are not. If accountability measures such as the No Child Left Behind Act are to be met, superintendents must empower instructional leaders to put in place research-based practices that bring $21^{\text {st }}$ century knowledge and skill sets to the students. This study presents a plethora of data on superintendent's leadership style and frame utilization. This study validates the equalization formula for schools in Ohio as it pertains to districts with lower fiscal capacity. It is also apparent districts that 
depend less on the state of Ohio for basic aid spend significantly more dollars per pupil than those that depend more on the state. From these results it becomes apparent districts with a greater fiscal capacity will always out do those who have less. How these dollars being spent must be scrutinized and the styles of the leaders that are spending these dollars most effectively must be investigated. Superintendents nationwide must step forward and lead the present educational reform. To be successful, superintendents must gain an understanding of leadership styles to effectively maneuver today's educational landscape.

Today's mobility of superintendents, one in four superintendents across Ohio serving their current school district fewer than six years, would indicate the need for the understanding of leadership styles. The study found superintendents across Ohio by both genders champion the multi-framed leadership style the most. This researcher believes this did not happen by chance. Given the conditions of superintendent leadership, matriculation to this position is one that is scaled by few. The years of experience and training combined with the challenges of the position make it a position that is not for all educators. From this study it was found those in this position overwhelmingly operate from the multi-framed style. Preparation programs for effective educational leaders must ensure future superintendents receive professional development activities encouraging them to become multi-framed in their leadership style.

As leadership studies go forward into the fourth generation of effective schools research, the investigation of the effect of leadership at the central office is a must. With current accountability systems in place central office personnel need a clear understanding of Bolman and Deal's leadership cognitive frames. A clear understanding 
of the structural, human-resource, political and symbolic frames will be most useful to today's and tomorrow's leaders in education. It only makes sense that multi-framed leaders have a wider arsenal of knowledge to deal effectively with more situations. Therefore, recommendations for practice would include:

1. We as professional learning communities must develop and plan high quality professional development to provide the opportunity for practicing superintendents to gain the knowledge and the skill sets necessary to understand their leadership styles through utilization of the framed leadership assessments of self and others. The Bolman and Deal instruments could be used to help heighten this awareness. A greater awareness of one's leadership style and perception of style by others would increase one's effectiveness as a leader.

2. In an instructional setting situations could be created requiring individuals to select the best frame(s) to handle the situation. An understanding of the cognitive leadership frames described by Bolman and Deal are not only important as an organization views itself, but perhaps more importantly by individual leaders. This knowledge and skill set will help educational leaders adjust accordingly to situations at hand.

3. Through a series of professional development activities the underlying goal would be to develop multi-framed leadership style leaders.

4. The same knowledge and skill sets discussed above must be implemented in superintendent training programs. Future educational leaders need to understand the benefits/consequences of framed leadership styles. 
5. As school districts undergo superintendent searches, an understanding of the complex interactions between student performance, district fiscal conditions and leadership styles must be conveyed to the decision-makers. Boards of Education and search committees must gain this valuable information to better select the candidate that is most likely to succeed in their environment.

6. School funding policy makers and legislators nationwide need to be made aware of the significant relationships that exist with a school district's' dependence on state basic aid and student performance. This awareness may be through the publication of professional papers that are published in literature subscribed to by these individuals.

\section{Recommendations for Further Studies}

Future studies on the effects of leadership styles and fiscal conditions of school districts must go forward in these times of educational accountability and poor economic conditions.

This study reports the frequency patterns of superintendent styles and leadership from utilization, while the relationships between leadership styles and the study variables the significance did approach the 0.05 level. To say leadership styles have no relationship with the study variables may not be true due to the small number of participants.

The study did find for the time period of the study (1997-2007), the equalization formula of funding in Ohio is taking place. It is apparent school districts in Ohio that receive more state basic aid had a greater percentage increase in per pupil expenditure than those that depend less. However, it was also found districts that depend on the State 
of Ohio for basic aid spend significantly less per pupil than those that depend on the state less. While the equalization formula is taking place those districts that depend on the state for basic aid still lag far behind in dollars spent per pupil!

Therefore recommendations for further studies would include:

1. As the fourth generation of effective schools research continues, more studies need to be completed on the leadership styles and practices of the superintendent. If similar studies have participant rates similar to this study, a power analysis study is suggested. The small number of participants in this study may have limited the significance of leadership styles. Consideration of Quasi-Experimental study would be beneficial.

2. To explore the why of the findings of this research, qualitative studies must be completed. These findings could lead to a deeper understanding of best practices and behaviors of the most effective superintendents.

3. Studies that compare and contrast the results of the perceptions of the leadership styles of superintendent by self and others need to be completed. This story could investigate the differences in the perceptions of leadership styles.

4. Future studies must be completed focusing on the fiscal condition of school districts and student achievement.

5. Future studies must focus on the relationships of a school district's dependency on state basic aid and the district's student performance. This needs a much deeper unwrapping and understanding. 
6. As studies investigating the effects of school size, socio-economic status, expenditure per pupil and gender with district student performance result in varied results, the need for more studies must be completed to bring greater reliability and validity.

7. Case studies need to be completed on individual school districts that rely heavily on state basic aid. Investigating the boom and bust funding cycles of these districts must be completed for a greater understanding of the effects of the study variables. These studies would bring a greater understanding of these district's types. 


\section{References}

Addonizio, M. F. (1997). Equality or choice? School Finance Reform and the income-expenditure relationship. Journal of Education Finance, 12(1), 22-42.

Ammar, S., Duncombe, W., Jump, B., \& Wright, R. (2005). A financial condition indicator system for school districts: A case study of New York. Journal of School Finance, 30(3), 231-258.

Arnold, M., Biscoe, B., Farmer, T., Robertson, D., \& Shapley, K.L. (2007). How the government defines rural has implications for educational policies and practices. National Center for Education Evaluation and Regional Assistance. U.S. Department of Education. REL 2007 - 010. p21.

Baker, B. D. (2005). The emerging shape of educational adequacy: From theoretical assumptions to empirical evidence. Journal of Education Finance, 30(3), 259 287.

Barker, B. (1986). Advantages of small schools (Report No. RC-015607). Las Cruces, NM: Clearinghouse on Rural Education and Small Schools. (ERIC Document Reproduction Service No. ED 265 988).

Bensimon, E. M. (1989). The meaning of "Good Presidential Leadership": A frame analysis. The Review of Higher Education, 12(2), 107-123.

Bensimon, E. A., Newumann, A., \& Birnbaum, R. (1989). Making sense of administrative leadership: The "1" word in higher education. (ASHE-ERIC Higher Education Report No.1). The George Washington University, Washington, D.C. 
Black, S. (2008). Leadership and learning. American School Board Journal, September, 56-59.

Bolman, L. G. (2001). Lee Bolman Web Page. Retrieved from http://www.bsbpa.umkc.edu/classes/bolman.

Bolman, L. (2003). Using leadership orientations. Section IV: Reliability of leadership orientation scales., retrieved from http://www.bsbpa.umkc.edu/classes/bolman/new page $1 . \mathrm{htm}$.

Bolman, L., \& Deal T. E. (1990). Leadership orientations. Brookline, MA: Leadership Frameworks.

Bolman, L. G., \& Deal, T. E. (1991). Image of leadership. (Report No. 7). Nashville, TN: National Center for Educational Leadership. (ERIC Document Reproduction Service No. ED 332 345)

Bolman, L. G., \& Deal, T. E. (1991). Leadership and management effectiveness: A multiframe, multi-sector analysis. Human Resource Management, 30(4), 509-534.

Bolman, L.G. \& Deal, T. E. (1992). Leading and managing: Effects of context, culture and gender. Education Administration Quarterly, 28(3), 314-329.

Bolman, L. G. \& Deal, T. E. (1992). Reframing leadership: The effects of leaders' images of leadership. In K. E. Clark, M. B. Clark, and D. Campbell (Eds.), Impact of leadership. Greensboro, NC: Center for Creative Leadership.

Bolman, L. G., \& Deal, T. E. (1993). Every day epistemology in school leadership: Patterns and prospects. In P. Hallinger, K. Leithwood, \& J. Murphy (Eds.), Cognitive Perspectives on Educational Leadership (pp. 21-33). New York and London: Teacher College Press. 
Bolman, L. G., \& Deal, T. E. (2003). Reframing organizations: Artistry, choice, and leadership ( $3^{\text {rd }}$ Edition). San Francisco, CA: Jossey-Bass.

Bolman, L. G., \& Deal, T. E. (2006). The wizard and the warrior: Leading with passion and power. San Francisco, CA: Jossey-Bass.

Bolman, L. G., \& Granell, E. (1999). Versatile leadership: A comparative analysis of reframing in Venezuelan managers. Paper presented at the World Conference of the Ibero-American Academy of Management, Madrid.

Borden, M.P. (2000). Leadership orientations of area campus administrators in Florida's state university and community college systems: A frame analysis. (Doctoral dissertation). University of Central Florida, 2000). Dissertation Abstracts International: 61(10A). (UMI Dissertation Services Item: 199990629).

Bowen, E. (2004). Perspectives on the leadership styles of West Virginia University Extension Service County program coordinators. (Doctoral dissertation). West Virginia University. Morgantown, WV

Brorsen, B. W., \& Jacques, C. (2000). Relationship between school district expenditures in various categories and student performance. Oklahoma State University Department of Agricultural Economics. Available at SSRN: http://ssrn.com/abstract=250948 or DOI: $10.2139 /$ ssrn.10.2139/ssrn.250948

Cantu, D. A. (1997). The leadership frames of academic deans randomly selected and nominated as exceptionally effective at public colleges. (Unpublished doctoral dissertation). Arkansas State University, Jonesboro, AK 
Card, D., \& Payne, A. (2002). School finance reform, the distribution of school spending, and the distribution of student scores. Journal of Public Economics, 88(1), 49-82.

Cavenaugh, S. (2007). Poverty's effect on U.S. scores greater than for other nations. Education Week, 27(15).

Chang, T. (2004). Leadership styles of department chairs and faculty utilization of instructional technology. (Unpublished doctoral dissertation). West Virginia University. Morgantown, WV.

Crist, B. E. (1999). A study of the relationship of the job satisfaction of chief academic officers of institutions of higher education and the perceived leadership style of the institution's president. (Unpublished doctoral dissertation). West Virginia University Morgantown, WV

Davis, T. I. (1996). The ways administrators work: A study of the theoretical frames of leadership used by female and male secondary school principals in Pennsylvania. Dissertation Abstracts International: (UMI No. 9632022)

DeAngelis, K. J., \& Presley, J. B. (2007). Leaving schools or leaving the profession: Setting Illinois' record straight on teacher attrition (ERIC 2007-1). Edwardsville, IL: Illinois Education Research Council.

Durocher, E. A. (1995). Leadership orientations of school administrators: A survey of nationally recognized school leaders. Dissertation Abstracts International: (UMI No. 9620148). 
Fowler W. Jr., \& Monk, D. (2001). A Primer for making cost adjustments in education: An overview. Selected Papers in School Finance 2000-01. U.S. Department of Education. Office of Education Research and Improvement. NCES 2001-378.

Geographic Academic Policy Series (GAP): Analyzing Achievement Gaps in Education. The National Office for Research, Measurement and Evaluation Systems (NORMES). University of Arkansas. Retrieved on July 5, 2008 from: http://normes.uark.edu/gaps/vol1n3.html

Glass, T., \& Franceschini, L. (2007). The state of the American superintendency: A mid-decade study. American Association of School Administrators. Lanham, MD. Rowman \& Littlefield Publishers Inc.

Green, J., \& Trivitt, J. R. (2008). Can judges improve academic achievement? Journal of Education, (83), 224-237.

Greene, G. (2005). Quality matters: A different perspective on the relationship between school resources and student outcomes. Dissertation Abstracts International: Section A. Humanities and Social Sciences. 66(5-A), 1576. Retrieved from http://www.il.proquest.com/umi/

Greene, G., Huerta, L., \& Richards, C. (2007). Getting real: A different perspective of the relationship between school resources and student outcomes. Journal of Education Finance, 33(1), 49 - 68.

Gregory, T. (2000). School reform and the no-man's-land of high school size. (ERIC Document Reproduction Service No. ED 451 981) 
Hirth, M., \& Eiler, E. (2005). Horizontal and vertical equity analysis of Indiana's 2001 reward for effort formula. Journal of Education Finance, 30(4).

Hopkins, T. (2005). If you are poor, it is better to be rural: A study of mathematics achievement in Tennessee. The Rural Educator, 27(1), 21-28.

Howley, C. B., Coe, P., Nash, R., \& Strange, W. (1989). Grassroots development: applying educational resources information center (ERIC) resources in a small, rural school district. In Education and the Changing Rural Community: Anticipating the $21^{\text {st }}$ Century. Proceedings of the 1989 ACRES/NRSSC Symposium. See RC 017257.

Howley, C. B., Howley, A., Howley C. W., \& Howley M. D. (2006). Saving the children of the poor in rural schools. Paper Presented at the annual meeting of The American Educational Research Association. San Francisco CA. April 2006. Ohio University, Athens, Ohio, Appalachian Collaborative Center for Learning, Assessment, and Instruction in Mathematics (ACCLAIM).

Howley, C. B. (1994). The academic effectiveness of small-scale schooling. Charleston, W.V.: ERIC Clearinghouse on Rural Education and Small Schools. (ERIC Document Reproduction Service No. ED 372 897)

Howley, C.B., \& Gunn, E. (2003). Research about mathematics achievement in the rural circumstance. Journal of Research in Rural Education, 18(2), 86 -95.

Huang, G., \& Howley, C. (1993). Mitigating disadvantage: Effects of small-scale schooling on student achievement in Alaska. Journal of Research in Rural Education, 9(3), 137-149. 
Jehlen, A. (2000). The wealth factor. NEA Today, 19(1).

Jimerson, L. (2001). The great balancing act: financial equity and local control. Can Vermont's act 60 do it? Paper presented at the American Educational Research Association annual meeting in Seattle WA. Northeast and Islands Regional Lab at Brown University. RI.

Johnson, J. D., Howley, C. B., \& Howley, A. A. (2002). Size, excellence, and equity: A report on Arkansas schools and districts. Charleston, WV: ERIC Clearinghouse on Rural Education and Small Schools. (ERIC Document Reproduction Service No. ED 459 987).

LeFevre, T. (2004). Report card on American education: A state by state analysis, 1981 - 2003. Washington DC American Legislative Exchange Council.

Mathis, S. G. (1999). The relationship of leadership frame use of departmental chairs to faculty job satisfaction as perceived by selected departmental faculty members. Dissertation Abstracts International: 60, 6-A.

Miller, P.A. (1998). Directors/Chairpersons of occupational therapy professional programs: A study of leadership in higher education. (Unpublished doctoral dissertation). Teachers College, Columbia University. New York, NY

Mosser, N. R. (2000). A study of the relationship between the perceived leadership style of nursing chairpersons and the organizational climate in baccalaureate nursing programs. Dissertation Abstracts International (UMI No. AA 19999952).

Muir, E. (2001). Smaller schools: How much more than a fad? American Educator, 24(4), 40-46. 
Murphy, J. (2001). Equity as student opportunity to learn. Theory in Practice, 27(2), $145-151$.

Murphy, J., Hallinger, P., \& Lotto, L. (1986). Inequitable allocations of alterable learning variables in schools and classrooms: Findings and suggestions for improvement. Journal of Teacher Education, 37(6), 21-26.

National Center for Education Statistics. (2006). School districts demographics system CCD public school data 2005-2006 school year. Retrieved from http://nces.ed.gov/surveys /sdds/main1.asp.

Odden, A. (1994). Decentralized management and school finance. Theory into Practice, 33(2), 104-110.

Odden, A. (2001). The new school finance. Phi Delta Kappan. September. 85-91.

Odden, A. \& Picus, L. (2007). School finance adequacy at a crossroads. Education Week. 26(45), 32-40.

Olson, L. (2008). When unequal is fair treatment. Education Week, 27(24).

Orr, A. (2003). Black-White differences in achievement: The importance of wealth. Sociology of Education. October. 76, 282-304.

Ohio Coalition for Equity and Adequacy of School Funding. (2001). DeRolph III: More money but the complete overhaul of DeRolph I and DeRolph II surrendered. $100 \mathrm{~S}$. Third St. Columbus $\mathrm{OH}$

Pan, D., Smith-Hanse, L., Jones, D., Rudo, Z., Alexander, C., Kahlert, R., \& Kahlert, R.(2004). Investigation of databases in four states to support policy research on research allocation. U.S. Department of Education. 
Peters, T. J., \& Waterman, R. H. (1982). In search of excellence. New York: Harper Collins.

Reschovsky, A., \& Imazeki, J. (2000). Achieving educational adequacy through school finance reform: A CPRE research report series. Consortium for Policy Research in Education. Philadelphia, PA. Retrieved June 16, 2006 through EBSCO Host.

Rivers, P. G. (1996). A frame analysis of principals' leadership orientations (multi-frame thinking). Dissertation Abstracts International: (UMI No. AAG9637016).

Roscigno, V. J., \& Crowley, M.L. (2001). Ruralality, institutional advantage and achievement attainment. Rural Sociology, 66, $268-293$.

Roza, M., \& Miles, M. H. (2002). Moving toward equity in school funding within districts: A comparison of traditional funding policies and more equitable formulas. Anneberg Institute for School Reform. Brown University. Providence, RI.

Sack, J. L. (2004). Aid disparities in needy schools seen are rising. Education Week. 24(7) $1-15$.

Salmon, R., \& Alexander, M. (1976). The concept of "Thorough and Efficient": A problem of definition. Virginia Polytechnic Institute and State University. Blacksburg, VA. (ERIC Document Reproduction Service No. ED 123 734)

Shafritz, J. M., Ott, J.S., \& Yang, S. J. (2005). Classics of organizational theory (6th Edition). Belmont, CA: Thompson-Wadsworth.

Sizer, T. R. (1996). Horace's hope: What works for the American high school? Boston, MA: Houghton-Mifflin. 
Skandera, H., \& Sousa, R. (2002). Can money buy better schools? Hoover Digest. 4. Retrieved from http://www.hoover.org/publications/digest/4495906.html\#t2.

Small, T. T. (2002). A study of the relationship between the perceived leadership style of nursing chairpersons and the organizational effectiveness of baccalaureate nursing programs. (Unpublished doctoral dissertation). West Virginia University. Retrieved from http://etd.wvu./templates/showETD.cfm?recnum=2424 .

Stankus, S. (2007). A study of the relationship between the leadership styles of principals in smaller learning communities, the number of structures and strategic configurations and rates of student success of $9_{\text {th }}$ graders. (Unpublished doctoral dissertation). West Virginia University. Morgantown, WV.

Sughrue, J. (1997). A trend analysis of Ohio's state funding for public and nonpublic school students. (Doctoral dissertation). Virginia Tech, Blacksburg, Virginia

Turley, C. L. (2002). Radiation therapy program directors: A frames analysis o leadership in higher education. (Unpublished doctoral dissertation). The George Washington University. Washington, DC.

Ulmer, M. (2002). Principal's leadership practices in the context of state assessments. (Doctoral dissertation). The University of Connecticut. Hartford, CN.

Viadero, D. (2001). Smaller is better. Education Week, 21(13), p. 28.

Waters, T.J., \& Marzano, R.J. (2006). School leadership that works: The effect of superintendent leadership on student achievement. McRel, September.

Waters, T.J., \& Marzano, R.J. (2007). The primacy of superintendent leadership. School Administrator, 64(3), 10-17. 
Waters, T.J., \& Marzano, R.J. \& McNulty, B. (2004). Leadership that sparks learning. Educational Leadership. 48-51.

Winters, J. J. (2003). An examination of eighth and twelfth grade students' mathematics achievement in relation to school locale, county location, looping status, SES, grade and class size, and access to upper-level mathematics courses in Tennessee. (Doctoral dissertation). University of Tennessee at Knoxville. Knoxville, TN. 


\section{APPENDICES}

A: Calculating the Performance Index

The PI is calculated by assigning a weighted score to each performance level in the following manner:

- Untested students - 0 points

- Below Basic/Limited - 0.3 points

- Basic - 0.6 points

- Proficient - 1.0 points

- Accelerated - 1.1 points

- Advanced - 1.2

The percentage of students at each performance level is then multiplied by their respective weight, and the totals for each performance level are summed to get the building's overall Performance Index score.

Example:

\begin{tabular}{|l|c|c|c|}
\hline Performance Level & \% of Students at Level & Weight & Score \\
\hline Untested & 5 & 0.0 & 0.0 \\
\hline Limited & 20 & 0.3 & 6.0 \\
\hline Basic & 25 & 0.6 & 15.0 \\
\hline Proficient & 35 & 1.0 & 35.0 \\
\cline { 1 - 3 } Accelerated & 5 & 1.1 & 5.5 \\
\hline Advanced & 10 & 1.2 & 12.0 \\
\hline \multicolumn{4}{|c}{ Performance Index Score: } \\
\cline { 3 - 4 }
\end{tabular}

$\%$ of Students at Level $*$ Weight $=$ Score

EXAMPLE: $20 * .3=6.0$

This is obtained by summing the scores:

$0+6+15+35+5.5+18=73.5$

The maximum possible PI score is 120 (100\% of students at advanced level). The minimum is zero (all students untested). 


\begin{tabular}{|l|l|}
\hline Performance Index - Count of Tests at that Performance Level \\
\hline Definition: & $\begin{array}{l}\text { This is the total number of tests that were taken by } \\
\text { students in grades 3, 4, 5, 6, 7, } 8 \text { and } 10 \text { (OGT) who } \\
\text { were enrolled in the district for a "full academic year" } \\
\text { broken down by performance level achieved. Students } \\
\text { who were required to take a test who did not take the } \\
\text { test would be in the "Untested" category. } \\
\text { Note: Students who are reported with REASON } \\
\text { "SUBJECT" TEST NOT TAKEN (WAIVER } \\
\text { REASON)="A' - Medical Reason - will be excluded } \\
\text { from all performance level calculations. }\end{array}$ \\
\hline Calculation: & $\begin{array}{l}\text { A count is taken by performance level of testing records } \\
\text { with a Required Test Type of "STR" or "ALT" for } \\
\text { students enrolled in the district for a "Full Academic } \\
\text { Year" in grades 3, 4, 5, 6, 7, 8 and 10 (OGT). } \\
\text { Note: Students that have been excluded from the } \\
\text { "PROFICIENT" level because of the 1.0\% cap } \\
\text { limitation will be included in the count of students } \\
\text { achieving at the Basic Performance Level. }\end{array}$ \\
\hline $\begin{array}{l}\text { Data } \\
\text { elements: }\end{array}$ & $\begin{array}{l}\text { STATE EQUIVALENT GRADE LEVEL } \\
\text { STUDENT STATUS } \\
\text { ATTENDING/HOME IRN INDICATOR } \\
\text { STUDENT PERCENT OF TIME } \\
\text { MAJORITY OF ATTENDANCE IRN } \\
\text { ACCOUNTABILITY IRN } \\
\text { REQUIRED TEST TYPE } \\
\text { TEST GRADE LEVEL } \\
\text { RAW/SCALED SCORE } \\
\text { REASON "SUBJECT" TEST NOT TAKEN } \\
\text { (WAIVER REASON) } \\
\text { WITHDRAWAL DATE } \\
\text { LEP }\end{array}$ \\
\hline
\end{tabular}




\begin{tabular}{|c|c|}
\hline Filter(s): & $\begin{array}{l}\text { Includes students who meet the following criteria: } \\
\text { Student Status = "0", "1", "3", "4", "5", "7", "8", "9", } \\
\text { "A", "C", "D", "L", "M", "S","W"; AND Student } \\
\text { Percent of Time > 0. } \\
\text { OR } \\
\text { Attending/Home IRN Indicator = " } 2 \text { ", " } 3 \text { ", " } 4 \text { ", " } 5 \text { " or } \\
6 \text { ". } \\
\text { OR } \\
\text { Students that your district sent to a special } \\
\text { education cooperative program at another district. } \\
\text { These students will be included in your district's } \\
\text { calculation based upon the data reported by the } \\
\text { district educating the student. The educating district } \\
\text { would report the students with student status = "B". } \\
\text { AND } \\
\text { - Student is enrolled in the district for a full academic } \\
\text { year as reported in the Majority of Attendance IRN } \\
\text { element. Refer to "Full Academic Year" definition for } \\
\text { additional details. } \\
\text { AND }\end{array}$ \\
\hline
\end{tabular}

Count of Tests at that Performance Level

After the first day of the current school year and students reported with a REASON "SUBJECT" TEST NOT TAKEN (WAIVER REASON) $=$ 'A' - Medical Reason.

Data Source:

Reported by district through EMIS in FY2007 Yearend $\mathrm{N}$ 


\begin{tabular}{|c|c|}
\hline \multicolumn{2}{|c|}{ Performance Index - Count of All Tests } \\
\hline Definition: & $\begin{array}{l}\text { This is the total number of test records for students in } \\
\text { grades } 3,4,5,6,7,8 \text { and } 10 \text { (OGT) who were enrolled } \\
\text { in the district for a "full academic year". These students } \\
\text { were required to take the achievement/OGT tests. All } \\
\text { test records for these students are counted } \\
\text { REGARDLESS of score or whether the student actually } \\
\text { took the "subject" test. Any student who met the criteria } \\
\text { in the "filter" section below, and was required to take a } \\
\text { test, would be included in this column (with the } \\
\text { exception of LEP students enrolled in US schools for } \\
\text { the first time on or after the first day of school of the } \\
\text { current school year and students reported with } \\
\text { REASON "SUBJECT" TEST NOT TAKEN } \\
\text { (WAIVER REASON) = medical reasons. }\end{array}$ \\
\hline Calculation: & $\begin{array}{l}\text { A count is taken of ALL test records with a Required } \\
\text { Test Type of "STR" or "ALT" for students in grades } 3 \text {, } \\
4,5,6,7,8 \text { and } 10 \text { (OGT) who were required to take } \\
\text { the achievement/OGT assessment tests and met the } \\
\text { criteria in the "filter" section below (with the exception } \\
\text { of LEP students enrolled in US schools for the first time } \\
\text { on or after the first day of school of the current school } \\
\text { year and students reported with REASON "SUBJECT" } \\
\text { TEST NOT TAKEN (WAIVER REASON) = Medical } \\
\text { Reasons. }\end{array}$ \\
\hline $\begin{array}{l}\text { Data } \\
\text { elements: }\end{array}$ & $\begin{array}{l}\text { STATE EQUIVALENT GRADE LEVEL } \\
\text { STUDENT STATUS } \\
\text { ATTENDING/HOME IRN INDICATOR } \\
\text { STUDENT PERCENT OF TIME } \\
\text { MAJORITY OF ATTENDANCE IRN } \\
\text { ACCOUNTABILITY IRN } \\
\text { REQUIRED TEST TYPE } \\
\text { TEST GRADE LEVEL } \\
\text { WITHDRAWAL DATE } \\
\text { REASON “SUBJECT” TEST NOT TAKEN } \\
\text { (WAIVER REASON) } \\
\text { LEP }\end{array}$ \\
\hline
\end{tabular}




\begin{tabular}{|c|c|}
\hline Filter(s): & 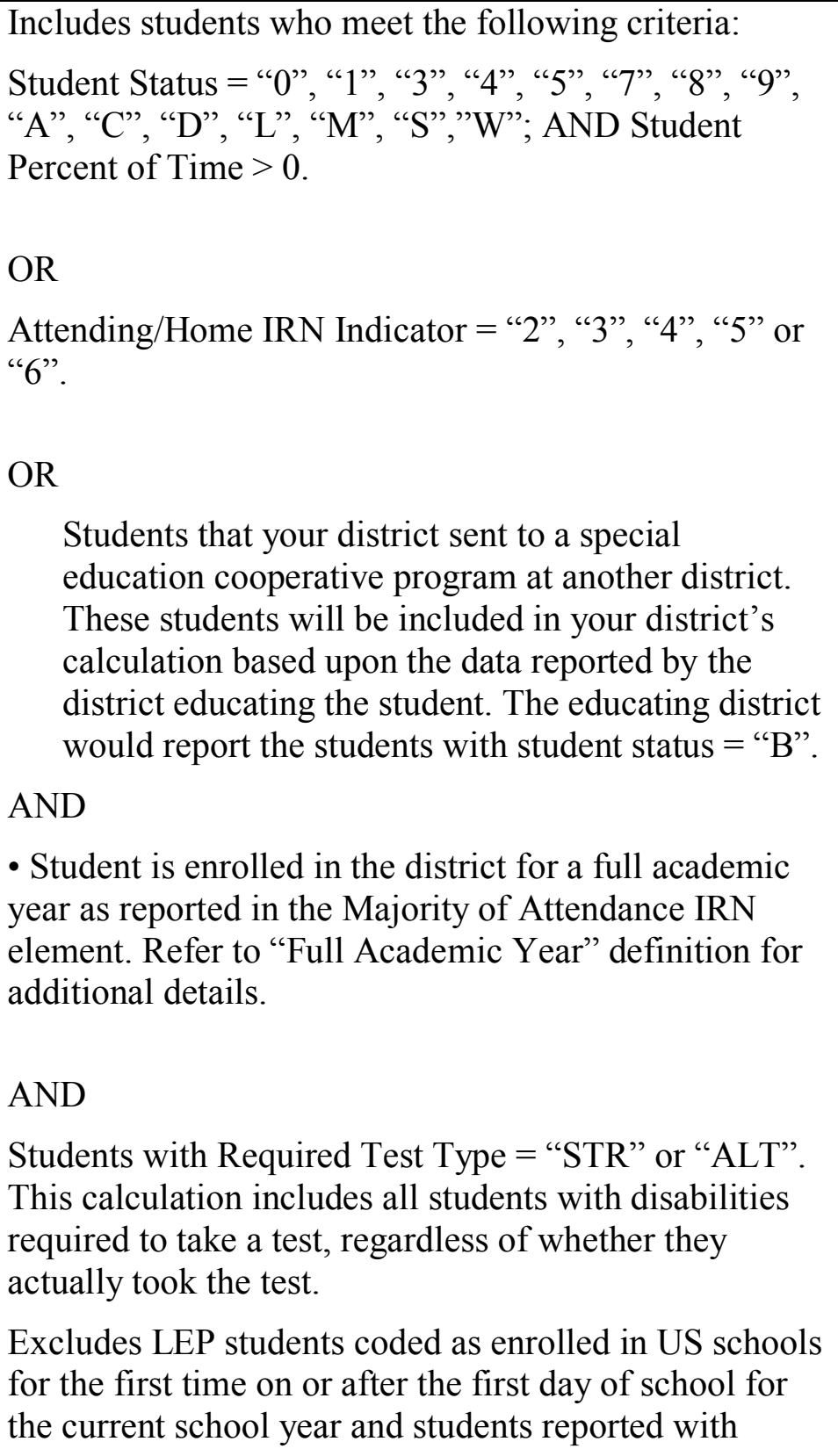 \\
\hline \multicolumn{2}{|c|}{$\begin{array}{l}\text { REASON "SUBJECT" TEST NOT TAKEN (WAIVER REASON })= \\
\text { medical reasons }\end{array}$} \\
\hline Data Source: & $\begin{array}{l}\text { Reported by district through EMIS in FY2007 } \\
\text { Yearend N }\end{array}$ \\
\hline \multicolumn{2}{|c|}{ Performance Index - Percentage by Performance Level } \\
\hline
\end{tabular}




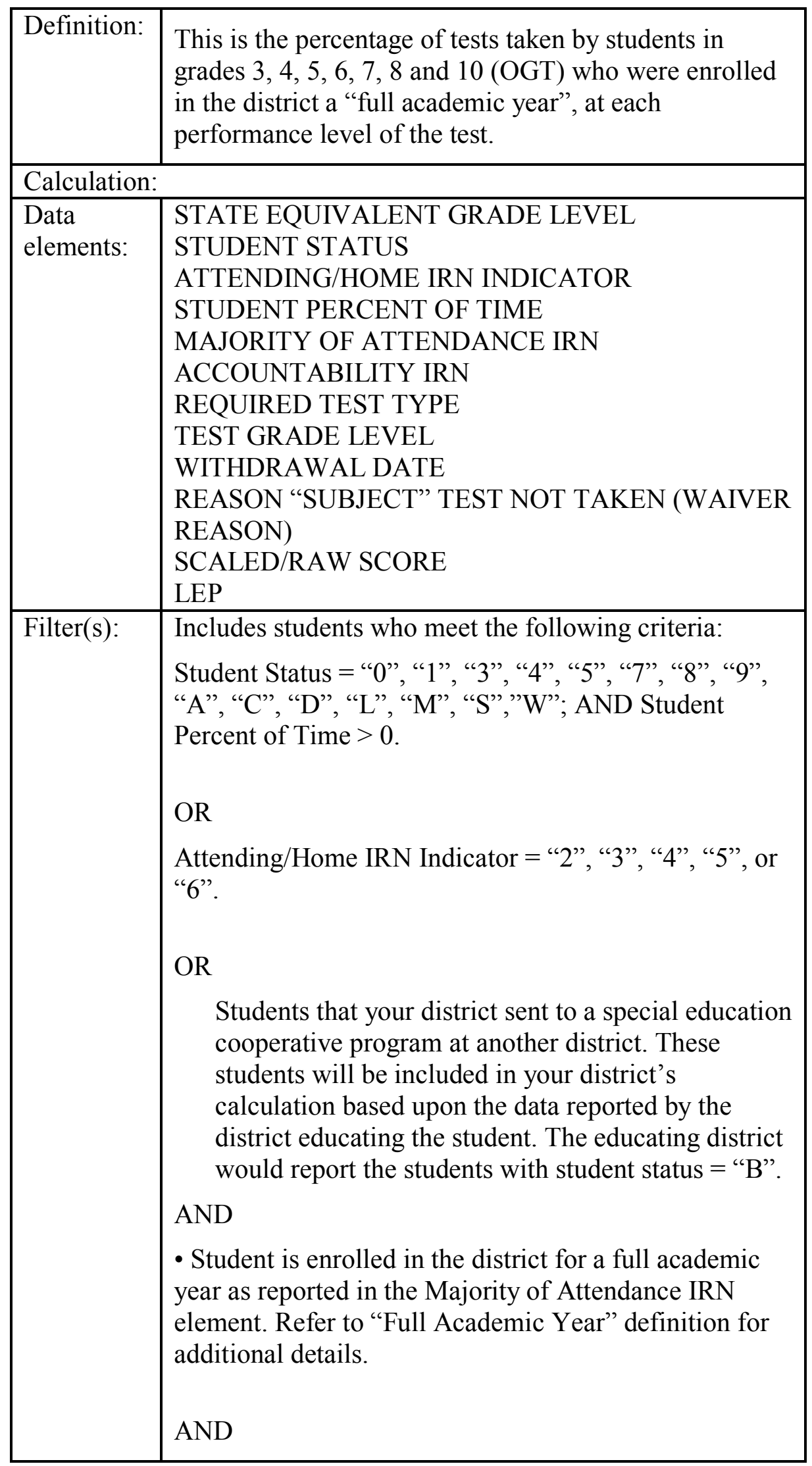




\begin{tabular}{|l|l|}
\hline & $\begin{array}{l}\text { Students with Required Test Type = "STR" or "ALT". } \\
\text { This calculation includes all students with disabilities } \\
\text { required to take the test, regardless of whether they } \\
\text { actually took the test. } \\
\text { Excludes LEP students coded as enrolled in US schools } \\
\text { for the first time on or after the first day of school for } \\
\text { the current school year and student tests coded with a } \\
\text { Medical Waiver. }\end{array}$ \\
\hline $\begin{array}{l}\text { Data } \\
\text { Source: }\end{array}$ & $\begin{array}{l}\text { Reported by district through EMIS in FY2007Yearend } \\
\text { N }\end{array}$ \\
\hline
\end{tabular}

$\%$ at each level

$$
=
$$

Number of Tests at each performance level

(Count of Tests at that Level)

Total number of Standard or Alternate test (Required Test Type of "STR" and "ALT") (Count of All Tests)

$\mathrm{x} 100$

Performance Index - Points (Weighted Score) 


\begin{tabular}{|c|c|}
\hline Definition: & $\begin{array}{l}\text { The Performance Index }(\mathrm{PI}) \text { is a calculation that } \\
\text { measures student performance on all achievement and } \\
\text { OGT tests based upon the number of test records at } \\
\text { each performance level. The PI is calculated by } \\
\text { assigning a weighted score to each performance level in } \\
\text { the following manner: } \\
\text { - Untested students - } 0 \text { points } \\
\text { - Limited - } 0.3 \text { points } \\
\text { - Basic - } 0.6 \text { points } \\
\text { - Proficient - } 1.0 \text { points } \\
\text { - Accelerated - } 1.1 \text { points } \\
\text { - Advanced - } 1.2 \\
\text { The percentage of tests at each performance level is } \\
\text { then multiplied by their respective weight, and the totals } \\
\text { for each performance level are summed to get the } \\
\text { district's overall Performance Index score. }\end{array}$ \\
\hline \multicolumn{2}{|l|}{ Calculation: } \\
\hline & $\begin{array}{l}\text { STATE EQUIVALENT GRADE LEVEL } \\
\text { STUDENT STATUS } \\
\text { ATTENDING/HOME IRN INDICATOR } \\
\text { STUDENT PERCENT OF TIME } \\
\text { MAJORITY OF ATTENDANCE IRN } \\
\text { ACCOUNTABILITY IRN } \\
\text { REQUIRED TEST TYPE } \\
\text { WITHDRAWAL DATE } \\
\text { REASON “SUBJECT” TEST NOT TAKEN (WAIVER } \\
\text { REASON) } \\
\text { SCALED/RAW SCORE } \\
\text { LEP }\end{array}$ \\
\hline Filter(s): & 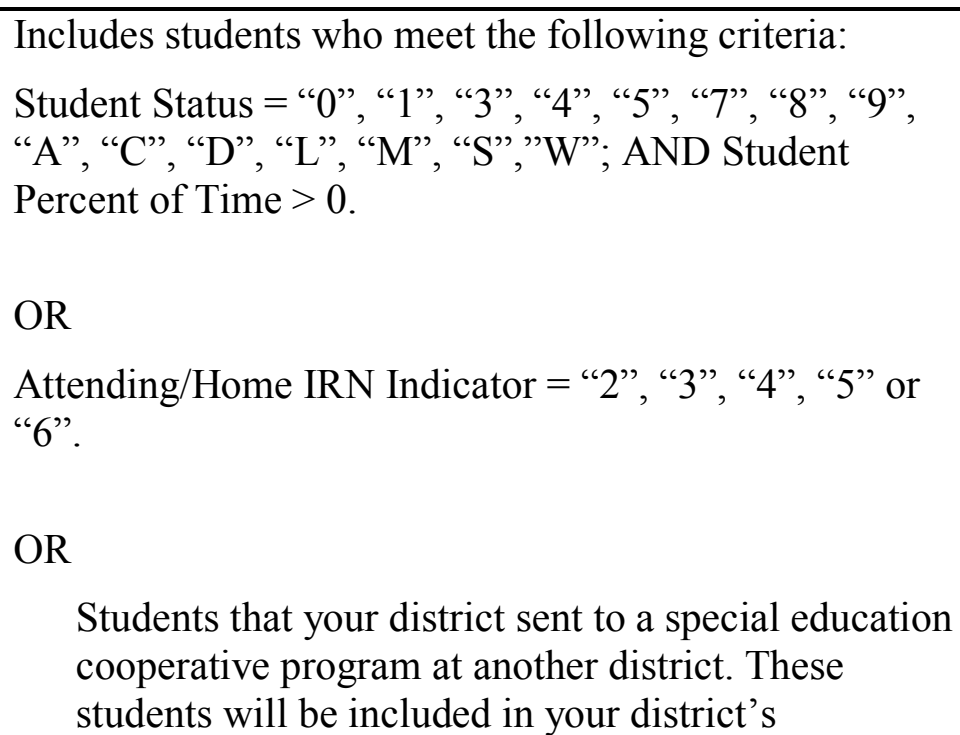 \\
\hline
\end{tabular}




\begin{tabular}{|l|l|}
\hline $\begin{array}{l}\text { calculation based upon the data reported by the } \\
\text { district educating the student. The educating district } \\
\text { would report the students with student status = "B". } \\
\text { AND }\end{array}$ \\
\hline
\end{tabular}

\section{Points}

$$
=
$$

Percentage of tests at a given Performance Level X Weight assigned to that level

Performance Index Score

$$
=
$$

Sum of Points at each Level of Performance 
Performance Index Performance Index - Points (Weighted Score)

\begin{tabular}{|l|l|}
\hline $\begin{array}{l}\text { OStudent is enrolled in the district for a full academic year as reported } \\
\text { in the Majority of Attendance IRN element. Refer to "Full Academic } \\
\text { Year" definition for additional details. } \\
\text { AND } \\
\text { Students with Required Test Type = "STR" or "ALT". This } \\
\text { calculation includes students with disabilities regardless of whether } \\
\text { they actually took the test. }\end{array}$ \\
$\begin{array}{l}\text { AND } \\
\text { Excludes LEP students coded as enrolled in US schools for the first } \\
\text { time on or after the first day of school for the current school year } \\
\text { AND students reported with REASON "SUBJECT" TEST NOT } \\
\text { TAKEN (WAIVER REASON) = A - medical reasons. }\end{array}$ \\
$\begin{array}{l}\text { Data Source: } \\
\text { Reported by district through EMIS in FY2007 } \\
\text { Yearend N }\end{array}$ \\
\hline
\end{tabular}

LRC 2006-07 Documentation 
B: Leadership Orientations (Self)

Your name:

\section{LEADERSHIP ORIENTATIONS (SELF)}

(C) 1990, Lee G. Bolman and Terrence E. Deal, all rights reserved

This questionnaire asks you to describe your leadership and management style.

\section{Behaviors}

You are asked to indicate how often each of the items below is true of you.

Please use the following scale in answering each item.

1

Never
2

3

Sometimes

Occasionally
4

5

Always

Often

So, you would answer ' 1 ' for an item that is never true of you, ' 2 ' for one that is occasionally true, ' 3 ' for one that is sometimes true of you, and so on.

Be discriminating! Your results will be more helpful if you think about each item and distinguish the things that you really do all the time from the things that you do seldom or never.

1. Think very clearly and logically.

2. Show high levels of support and concern for others.

3. Have exceptional ability to mobilize people and resources to get things done.

4. Inspire others to do their best.

5. __ Strongly emphasize careful planning and clear time lines.

6. Build trust through open and collaborative relationships.

7. Am a very skillful and shrewd negotiator. 
8. Am highly charismatic.

9. ___ Approach problems through logical analysis and careful thinking.

10. Show high sensitivity and concern for others' needs and feelings.

11. Am unusually persuasive and influential.

12. Am able to be an inspiration to others.

13. __ Develop and implement clear, logical policies and procedures.

14. Foster high levels of participation and involvement in decisions.

15. ___ Anticipate and deal adroitly with organizational conflict.

16. Am highly imaginative and creative.

17. Approach problems with facts and logic.

18. Am consistently helpful and responsive to others.

19. A__ Am very effective in getting support from people with influence and power.

20. Communicate a strong and challenging sense of vision and mission.

21. Set specific, measurable goals and hold people accountable for results.

22. Listen well and am unusually receptive to other people's ideas and input.

23. Am politically very sensitive and skillful.

24. See beyond current realities to generate exciting new opportunities.

25. Have extraordinary attention to detail.

26. __ Give personal recognition for work well done.

27. ___ Develop alliances to build a strong base of support.

28. Generate loyalty and enthusiasm.

29. Strongly believe in clear structure and a chain of command.

30. Am a highly participative manager.

31. Succeed in the face of conflict and opposition. 
32. Serve as an influential model of organizational aspirations and values.

\section{Leadership Style}

This section asks you to describe your leadership style. For each item, give the number "4" to the phrase that best describes you, "3" to the item that is next best, and on down to "1" for the item that is least like you.

1. My strongest skills are:

a. Analytic skills

b. Interpersonal skills

c. Political skills

d. Ability to excite and motivate

2. The best way to describe me is:

a. Technical expert

b. Good listener

c. Skilled negotiator

d. Inspirational leader

3. What has helped me the most to be successful is my ability to:

a. Make good decisions

b. Coach and develop people

c. Build strong alliances and a power base

d. Energize and inspire others

4. What people are most likely to notice about me is my:

a. Attention to detail

b. Concern for people

c. Ability to succeed, in the face of conflict and opposition

d. Charisma. 
5. My most important leadership trait is:

a. Clear, logical thinking

b. Caring and support for others

c. Toughness and aggressiveness

d. Imagination and creativity

6. I am best described as:

a. An analyst

b. A humanist

c. A politician

d. A visionary

\section{Overall rating}

Compared to other individuals that you have known with comparable levels of experience and responsibility, how would you rate yourself on:

1. Overall effectiveness as a manager.

1

2

3

4

5

Bottom 20\% Middle 20\% $\quad$ Top $20 \%$

2. Overall effectiveness as a leader.

1

2

3

4

5

$\begin{array}{lll}\text { Bottom } 20 \% & \text { Middle } 20 \% & \text { Top } 20 \%\end{array}$

\section{Background Information}

1. How many years have you served in your present Superintendency?

2. Male

Female

3. School District: 
C: Letter for permission to use Leadership Orientations (Self) Instrument

Lee G. Bolman

Marion Bloch/Missouri Chair in Leadership

Bloch School of Business and Public Administration

University of Missouri-Kansas City

5100 Rockhill Road

Kansas City, MO 64110

Dear Dr. Bolman:

I am a doctoral candidate in Higher Education Administration at West Virginia University and am preparing my dissertation prospectus. The title is "The Influence of the Leadership Styles of Superintendent's and Fiscal Conditions on District Student Performance across Ohio: A Post Hoc Study." It is my hope that you will grant permission to use your Leadership Orientations (Self) instrument to examine this relationship. I understand that, should you grant permission, I will provide to you a copy of any reports, publications, papers or theses resulting from this research. I also agree to provide a copy of the data file from this research if you request it.

I have found your research on leadership images and frames most interesting. With your permission to use the survey, upon completion of my research more information will be made available to you.

If you have any questions, you may contact me by email at dan.doyle@omeresa.net, by phone 304-281-5348 or by mail at 304 Washington Ave., Wheeling, W.V. 26003.

Again thank you for considering my request.

Sincerely,

Dan Doyle

Doctoral Student

Educational Leadership Studies

West Virginia University

Advisor: Dr. Richard Harnett 
D: Initial Introduction Letter to Superintendents across Ohio

Dear Superintendent of Schools:

You are serving in the most influential position in the public educational system of Ohio. You have been selected to participate in a study which will investigate the influence of superintendents' leadership styles and the fiscal conditions of school districts on student achievement.

I am completing a doctoral study at West Virginia University in Morgantown, WV. As a practicing Superintendent in Ohio I know we are all very busy serving our stakeholders; however, findings gained through this study will not only provide our profession information to develop our practices around, but also may provide necessary information to the decision-makers of Ohio to create a constitutional system of school funding.

Your participation in this study is entirely voluntary, and you do not have to respond to every item or question. Your signature is not required on this questionnaire. Your responses will remain anonymous, and confidentiality will be maintained. The questionnaire has been reviewed by educational professionals and will take approximately 10 minutes to complete. For a copy of the results of this survey, please send your email request to dan.doyle@,omeresa.net.

The questionnaire and survey can be accessed and submitted at www.leadershipimagesurvey.com Return of your completed questionnaire and survey before March 31, 2009 would be greatly appreciated.

Sincerely,

Dan Doyle

Doctoral Candidate

Department of Educational Leadership Studies 
E: Follow up Cover Letter to Superintendents across Ohio

Superintendent of Schools

Dear

Your position as a school leader involves enormous responsibility and a commitment of time. All of us are busier these days than we would like and most of us have a difficult time staying ahead of the obligations which are essential and required.

You may recall my e-mail you received earlier last month regarding a study of the influence of Superintendent Leadership Styles and Fiscal Conditions on District Student Performance Across Ohio. Because your response is so important to this study, I am requesting you take a few minutes out of your busy day to complete the questionnaire and survey.

I encourage you to take ten minutes (estimated time) out of your day and complete the questionnaire at www.leadershipimagesurvey.com. As indicated earlier, a summary of the results of this study may be obtained by sending your email request to dan.doyle@omeresa.net.

Your assistance in this research study is greatly appreciated.

Sincerely,

Dan Doyle

Doctoral Candidate

Department of Educational Leadership Studies 


\section{F. Approval for Expedited-IRB Protocol Exemption}

\section{Pe West Viginial Snversity ofrece of Resented complisace}

\section{Expedited-IRB Protocol-Exemption}

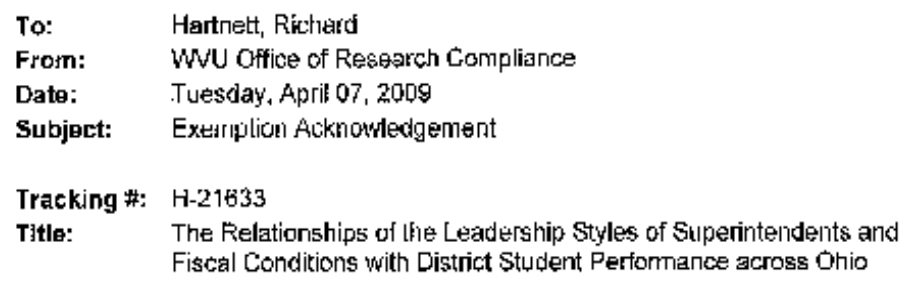

The above-reterenced study was reviewed by the West Virginia University Institulional Review Board (IRB) and was granted exemption in accordanca with 45 CFR 46.101(2)

This pratacol was reviewed usilzg the following:

Exemption Checklist (210r)

This research study was granted an exemption in accordance with Educaticna tests, survey procedures, interview procedures, or observation of public behavior [45 GFR 46.101(2)]

The following documents have been acknowledged for use in this study and are available in the BRAAN system:

Cover Letter

Follow up letter

Thank you.

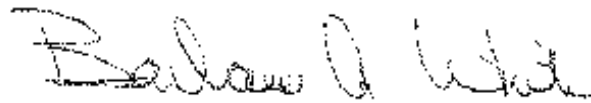

Board Designee: White, Bariara

Letler Sent By: White: Barbara, 4//2009 12:07 PM 
G. Certificates of Human Participant Protection Training

Completisn Report

Page 1 of t:

CITI Callaborative Institutional Training Initiative

Human Research Curriculurn Completion Report Frinted on Tuesday, February 12, 2008

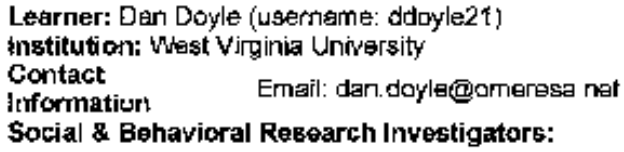

Stage 2, Refresher 2 Course Passed on 02 12/09 (Ref \# 1501737)

\begin{tabular}{|c|c|}
\hline Required Modthles & \begin{tabular}{|l} 
Datt \\
Completed
\end{tabular} \\
\hline SBR f01 REFRESHER MODULE 1. History and Ethics & $02 / 12 / 03$ \\
\hline SAR 101 REFRESHER MODULE 2. Regulalon Or Wrilew & $02 \sqrt{12 / 06}$ \\
\hline SBR 101 REFRESHER MODULE 3. Fundamental Issues. & $02 / 12 / 08$ \\
\hline SBR 101 REFRESHER MODULE 4. Vulnerabie Subjects & $02 / 12 / 068$ \\
\hline SBR 101 REFRE\$HER MODLLE 5. Additierlal Topics & $02 / 92 / 08$ \\
\hline $\begin{array}{l}\text { How to Complete The CITI Refresher Course and Receive the } \\
\text { Completion Report }\end{array}$ & $02 / 12 / 08$ \\
\hline West Virginia Uriversity & $02 / 12 / 000$ \\
\hline
\end{tabular}

For this Complettan Report to be valld, yle leamer Ilsted above must be affillated with a CITI participating Inststutlon. Falsifled information and unauthorized use of the clT course site is unethical, and may be considered scientific mlsconduct by your Institution.

Paul Bratunschweiger Ph. D

Professor: University of Miarni

Director Office of Research Education

CITI Course Coordinator

Eetum

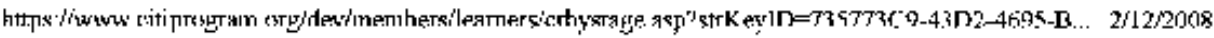

G. Certificates of Human Participant Protection Training (continued) 
C.ITI Cusursp in The Protection of Human Research Subjects

Human Resiarch Currlcuium Completion Report

Printed on Sunday, March 25, 2007

Learner: Dan Doyle (username: tidryle?)

Institution: West Virginia University

Contest

information:

Em:ail: dar.doylc@omeresa.net

Social \& Behavioral Research Investigators:

Stago 1. Basic Course Passed on 03/25/0? (Ref \# 953792)

Required Modules

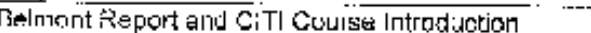

Defining Research wilti human Subjects - Ser

$03 / 25 / 07$

The Regulations ard the Social and Bebavioral Sciences - SRR $0 \overline{J / 25 / \mathrm{C} 7}$

\begin{tabular}{l|l|l|l|l}
\hline Assessing Risk in social and Behavioral Sciences - SBR & $03 / 25 / \bar{C}$
\end{tabular}

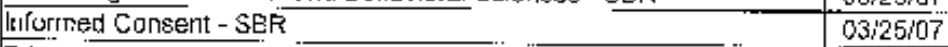

\begin{tabular}{ll|l}
\hline Privacy and Confidcrtieity - SBR &. & $03 / 25 / 07$ \\
\hline
\end{tabular}

\begin{tabular}{ll|l} 
Research writh Children - SBR & $03 i 25 / 07$ \\
\hline
\end{tabular}

HIPAA and I luitlan Sub,ects Kesearch

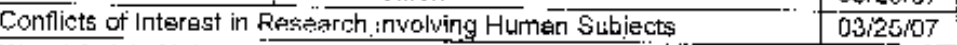

West Virginia University

For this Completion Roport to be valid, tha learnar listed above must be affiliated with a CITI participating institution. Folsified information and unauthorized use of the CITI course site is unethical, and may be considered stientifie misconduct by your ingtitution.

Pall Eraurschwciger Ph.D.

Professer. University of Miami

Diractor Office of Rescalch Education

C:Tl Ceurse Conrdingtor 
Vita

\section{Daniel T. Doyle}

The researcher has been an educator in Ohio K-12 public schools for over 34 years in the capacity of teacher, coach and administrator. The largest portion of his experience has been in the area of administration, the last nine years serving as Superintendent of Schools in a small rural school district located in Southeast Appalachia Ohio.

He was born on July 21, 1955, completing his undergraduate work in Pennsylvania and his Masters work in Ohio. He earned a Bachelor's Degree in Geology from Allegheny College, Meadville and a Masters in Administration from the University of Dayton.

He intends to pursue his research interests in leadership studies and school finance and would like to increase his involvement with policy development. He is interested in associating with a university or educational foundation.

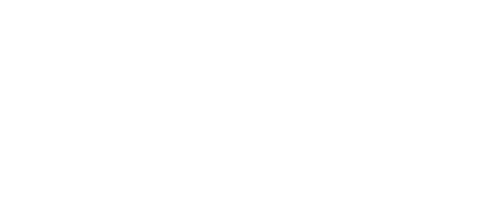

